\title{
Çok Katlı Yapılarda Betonarme Döşeme Sistemleri / İstanbul Örneği
}

\author{
Uğur Özcan ${ }^{1 *}$, Gökhan Duran ${ }^{2}$, İbrahim Erol $^{3}$ \\ ${ }^{1}$ Fatih Sultan Mehmet Vakıf Üniversitesi, Mimarlık Fakültesi, Mimarlık Bölümü, İstanbul, Türkiye (ORCID: 0000-0003-0002-4478) \\ ${ }^{2}$ Fatih Sultan Mehmet Vakıf Üniversitesi, Lisansüstü Eğitim Enstitüsü, Mimarlık Anabilimdalı, İstanbul, Türkiye (ORCID: 0000-0001-5042-8492) \\ ${ }^{3}$ Fatih Sultan Mehmet Vakıf Üniversitesi, Lisansüstü Eğitim Enstitüsü, Mimarlık Anabilimdalı, İstanbul, Türkiye (ORCID: 0000-0002-3092-7128)
}

(İlk Geliş Tarihi 10 Eylül 2019 ve Kabul Tarihi 14 Ekim 2019)

(DOI: 10.31590/ejosat.618084)

\begin{abstract}
ATIF/REFERENCE: Özcan, U., Duran, G. \& Erol, İ. (2019). Çok Katıı Yapılarda Betonarme Döşeme Sistemleri / İstanbul
\end{abstract} Örneği. Avrupa Bilim ve Teknoloji Dergisi, (17), 161-175.

\begin{abstract}
$\ddot{\mathbf{O z}}$
Bireylerin çeşitli fonksiyonel davranışlarını mekânsal olarak karşılayan şehirlerin, arazi değerleri yüksektir. Arazinin verimli kullanımına katkı sağlayan çok katlı yapılar, bina izdüşümünün azaltılarak daha fazla yeşil alan kazanılabilmesine imkan sağlamaktadır. Günümüzde oldukça yaygınlaşan karma yapı kullanımları, çok katlı yapılar sayesinde daha avantajlı hale gelebilmektedir. Çok katlı yapıların prestij unsuru olarak görülmesi ile konut ve ticari alan ortak kullanımı adeta altın çağını yaşamaktadır. Bu durumun gelişmesinde destekleyici unsur olan fonksiyonel ihtiyaçlar, aslında yapım yöntemlerindeki gelişmeler sayesinde gerçekleşebilmiştir. Yüksek yapıların inşa edilebilmesinde, betonun işlevselliğinin ve mukavemetinin arttırılması, kalıp sistemlerinin geliştirilmesi ve diğer teknolojik gelişmeler önemli rol oynamaktadır. Çok katlı yapılar, taşıyıcı sistemler ve döşeme sistemleri ile diğer yapılardan ayrılmaktadır. Bu noktada, çerçeve sistemler, çekirdek sistemler, kirişsiz döşemeli sistemler, perde duvarlı sistemler, kafes duvarlı çerçeve ve perde duvarlı çerçeve sistemler, mega kolon ve mega çekirdek sistemler, yatay perdeli çerçeve sistemler, tüp sistemler ve karma sistemler çok katlı yapılarda kullanılan taşıyıcı sistemler olarak karşımıza çıkmaktadır. Bu sistemler, kirişli, kirişsiz, nervürlü, kaset, ön germeli veya ard germeli döşeme sistemleri ile entegre edilerek yapılarda ihtiyaç duyulan alanların sağlıklı bir biçimde oluşturulabilmesine imkan sağlamaktadır. İstanbul'da yer alan yirmi beş adet çok katlı yapı seçilerek, bu yapıların taşıyıcı sistemleri karşılaştırılmışıı. Taşıyıcı sistemleri ve betonarme döşeme sistemleri incelenen bu örnekler, gelecekte yapılması planlanan çok katlı yapılar için bir kaynak oluşturabilecektir. Buna göre, İstanbul'da araştırma için belirlenmiş olan yirmi beş adet çok katlı yapının birçoğunda taşıyıcı sistem olarak çekirdek ve çerçeve tüp / kolon sistemlerin kullanıldığı görülmüştür. Söz konusu yapıların döşeme sistemleri incelendiğinde ise kaset ve iki doğrultuda çalışan kirişli döşeme sistemlerinin ağırlıkla kullanıldığı görülmüştür.
\end{abstract}

Anahtar Kelimeler: Yapı, Çok Katlı Yapı, Taşıyıcı Sistem, Betonarme, Betonarme Döşeme.

\section{Concrete Flooring Systems in Multi-Storey Structures / Istanbul Example}

\begin{abstract}
The cities, which meet various functional behaviors of individuals spatially, have high land values. Multi-storey buildings that contribute to the efficient use of the land allow for more green space by reducing building footprint. Today, the use of mixed structures, which are quite common, can become more advantageous thanks to the multi-storey structures. The common use of residential and commercial spaces is almost living its golden age after The multi-storey buildings are seen as prestige element. Functional needs, which support the development of this situation, have in fact been realized thanks to improvements in construction methods. Increasing the functionality and strength of concrete, development of formwork systems and other technological developments play an important role in the construction of high structures. Multi-storey buildings are separated from other structures by their load bearing structural systems and flooring systems. At this point, frame systems, core systems, beamless flooring systems, curtain wall systems, lattice wall frame and curtain wall frame systems, mega column and mega core systems, horizontal curtain frame systems, tube systems and mixed systems are seen as load bearing structural systems used in multi-storey structures. These systems can be integrated with beamed, beamless, ribbed, cassette, pre-tensioned or post-tensioned flooring systems, enabling the areas required in the structures to be formed in a healthy way. Twenty-five multi-storey buildings in Istanbul were selected and their
\end{abstract}

* Sorumlu Yazar: Fatih Sultan Mehmet Üniversitesi, Mimarlık Fakültesi, Mimarlık Bölümü, İstanbul, Türkiye (ORCID: 0000-0003-0002-4478), uozcan@ @sm.edu.tr 
structural systems compared. These samples whose structural systems and reinforced concrete flooring systems will be examined will be a source for multi-storey buildings in the future. Accordingly, core and frame tube / column systems were used in most of the twenty-five multi-storey buildings identified for research in Istanbul. When the flooring systems of these structures are examined, it is seen that beamed flooring systems which are working in two directions and casette flooring systems are used predominantly.

Keywords: Building, Multi-Storey Building, Structural System, Reinforced Concrete, Reinforced Concrete Flooring.

\section{Giriş}

Amerika Birleşik Devletleri'nde 1870'lerde, büyüyen iş hacimleri ve şehir merkezlerindeki nitelikli alanların azalması gibi nedenlerle, ofis binalarının kat sayıları artmaya başlamıştır. Bununla birlikte, yine aynı dönemde çok katlı binaların sembolik ve prestij değeri gündeme gelmiştir. Yapı malzemelerinde, yapım tekniklerinde, taşıyıcı sistemlerde ve düşey sirkülasyon elemanlarında ortaya çıkan gelişmelerin katkısı ile, on katı geçen binalar yapılmaya başlanmıştır. Söz konusu dönemde çevresindeki diğer binalara göre oldukça yüksek olan bu tip binalara İngilizcede "Skyscraper" (Gökkazıyan) adı verilmiştir. Diğer dillerdeki karşılıkları ise Almanca'da "Wolkenkratzer" (Bulutkaşıyan), Fransızca'da "Gratte - Ciel” (Gökkaşıyan) olmuştur. Günümüzde ise bunların yerine, İngilizcede "Tall Building” ve Almancada "Hochhaus" kelimeleri kullanılmaktadır. Bunların Türkçe karşılığı olarak ise, "Çok Katlı Yapı" terimi tercih edilmiştir.

Çok katlı binalar için, yükseklik kavramının göreceli olmasından dolayı, belirli bir yükseklik / kat tanımlaması yoktur. Bununla birlikte, söz konusu binaların çok katlı sayılabilmesi için bazı ülkeler yükseklik/kat sınırı getirmiştir. Örneğin; Amerika'da on iki kat ve üzeri yapılar, Almanya’ da ise giriş dahil olmak üzere yirmi iki metreyi aşan yapılar çok katlı bina statüsünü kazanmaktadırlar.

Sanayi devrimiyle birlikte dünya dengesi değişmiş zirai çalışma alanları, cazibesini sanayileşmeye kaptırmıştır. Bu gelişmeler öncülüğünde, kırsaldan şehre göç başlamıştır. Bu göç beraberinde hızlı, orantısız bir şekilde şehirleşmenin artmasını ve bunun beraberinde barınacak alan ihtiyacını artırmıştır. Arazi, fiyat-kullanım oranı ve arz-talep dengeleri bakımından ulaşılabilir olmaktan çıkmış bu durum yatay mimari yerine dikey mimari ihtiyacını doğurmuştur.

1800'lerden itibaren artan imkânlar ve gelişen teknolojiler, bireyler üzerinde farklı ihtiyaçlar ve istekler doğurmuştur. Bu gelişmeler bireylerin temel ihtiyaçlarından olan yaşama ve çalışma alanlarını tasarlarken de etkili olmuştur. Çok katlı yapı tasarımı böylelikle tarih sahnesinde yerini almaya başlamıştır. Çok katlı binalar başlarda çalışma ve ofis alanı olarak kullanılırken daha sonraları konut ve karma yapı projeleri olarak ihtiyaçlara cevap vermeye başlamıştır.

Şehir nüfuslarındaki hızlı artış beraberinde yoğun bir yapılaşmayı da getirmiştir. Çok katlı yapıların tercih edilmesindeki diğer bir sebep ise, artan bina yoğunluğu içerisinde yeşil alanların kısıtlanması ve azalmasıdır. Yapılaşma dikey doğrultuda olduğu için bireylerin kapalı alan ihtiyaçları, daha küçük bina taban alanları ile karşılanarak, daha fazla yeşil alan oluşturulabilmesine imkân tanımaktadır.

Teknolojik gelişmelerle birlikte yeni yapım teknikleri ortaya çıkmıştır. Bu yenilikler çok katlı yapıların inşa edilmesine olanak sağlamıştır. Gelişen yeni yapı iskeletleri sayesinde daha az duvara sahip, daha verimli kullanım alanları üretilmiştir. Yeni teknikler çelikle betonun bir arada daha etkin kullanılmasına olanak tanımıştır. Bireylerin dikey yönde hareketini kolaylaştıran asansörün icadıyla üst katlara ulaşım, daha hızlı ve rahat bir şekilde sağlanmıştır.

1960’lı y1llarda beton kalitesinin iyileştirilmesi, yatay ve düşey olarak büyük açıklıklara beton pompalayan pompaların faaliyete geçmesi, hafif betonun geliştirilmesi, çeşitli katkı maddeleriyle betonun işlenebilirliğinin yükseltilmesi, kendi kendine tırmanan kalıpların kullanılmaya başlanması ve prefabrikasyonun geliştirilmesi, çok katlı yapı üretimi teknolojisini bugünkü düzeye getirmiştir. Bununla birlikte, araştırma teknikleri ve temel sistemlerindeki gelişmeler, çok katlı bina yapımındaki zorlukların aşılabilmesine imkân vermiş, yapıların düşeyde yükselebilmesine olanak tanımıştır. (Yünüak, 1996).

\section{2. Çok Katlı Yapılarda Kullanılan Taşıyıcı Sistemler}

\section{1. Çerçeve Sistemler}

Çerçeve sistemler, üç temel başlık altında incelenebilir. Bunlar, takviyeli çerçeve, rijit çerçeve, çerçeve ve kafes kiriş birleşimi sistemlerdir. Çerçeve sistemler, 20. Yüzyılın başlarından itibaren çok katlı yapılarda taşıyıcı sistem olarak görülmeye başlanmıştır. Takviyeli çerçeve sistemler, çok katlı yapılarda, yanal yüklerin ve taşıyıcı elemanlardaki zorlanmaların kabul edilebilir sınırlarda tutulabilmesi için tercih edilmektedir. Burada amaç, betonarme veya kafes kiriş türü elemanlar kullanılarak taşıyıcı sistemin tümünün stabilitesinin sağlanabilmesidir. Rijit Çerçeve Sistemlerde, yatay ve düşey elemanlar tam rijit olacak şekilde birbirilerine bağlanırlar. Bu bağlantıların yapıldığı düğüm noktaları, kolon ve kirişlerin aralarında oluşturdukları açının zorlanarak değişmesini önleyebilmek ve çerçeve elemanlarının üzerinde oluşan yatay yük zorlamalarını karşılayabilmek için kullanılmaktadır. Çerçeve ve kafes kiriş birleşimi sistemler, çerçeve sisteminin ve kafes kiriş sisteminin bir bileşenidir. Çerçeve sistemin düşey yükler karşısında ve kafes kiriş sisteminin yanal yükler karşısında taşıdıkları avantajlar, bir araya getirilmek istenmiştir. Böylece, inşa edilecek yapının üst katlarında çerçeve, alt katlarında ise kafes kiriş sistemi kullanılması prensibi ile sistem oluşturulmaktadır. 


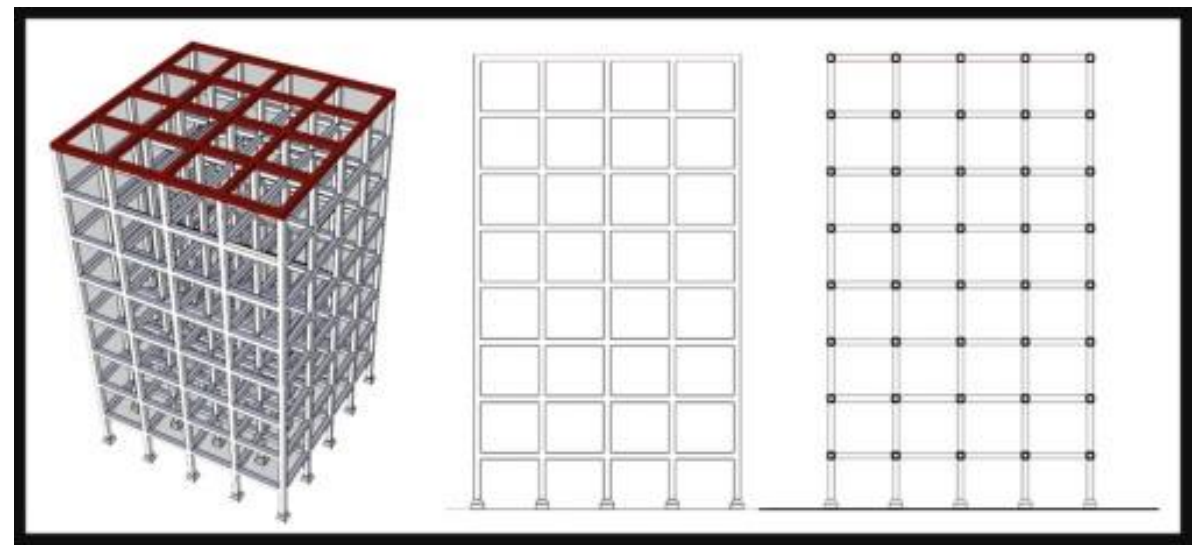

Resim 1: Çerçeve Sistemler Perspektif, Görünüş ve Kesiti

\section{2. Çekirdek Sistemler}

Çekirdek sistemler, perdelerin birleşmesiyle meydana gelen dikey taşıyıcılardır. Yatay ve dikey doğrultuda rijitleşmiş perde gibi davranırlar. Çalışma sistemi yelkenli gemilerin ana direklerinin çalışma şekline benzer. Bu sistem kullanılarak, geminin yelkenlerine gelen rüzgâr kuvvetlerinin bütününün ana direğe gitmesi önlenmiştir. Böylece, daha uzun ve küçük çaplı ana direğin yelkenler vasıtasıyla gelen yükleri taşıması sağlanmıştır (Sağlam, 2016). Çekirdek perde duvar genellikle açık çekirdek olup kat kirişi ve döşemesiyle kısmi kapalı çekirdek haline gelir. Yanal yükleme altında, yapıdaki muhtemel burulmaya karşı ideal olan kapalı çekirdek davranışına, kısmi kapalı çekirdekle yaklaşılmaya çalışılır (Günel ve Ilgın, 2010).

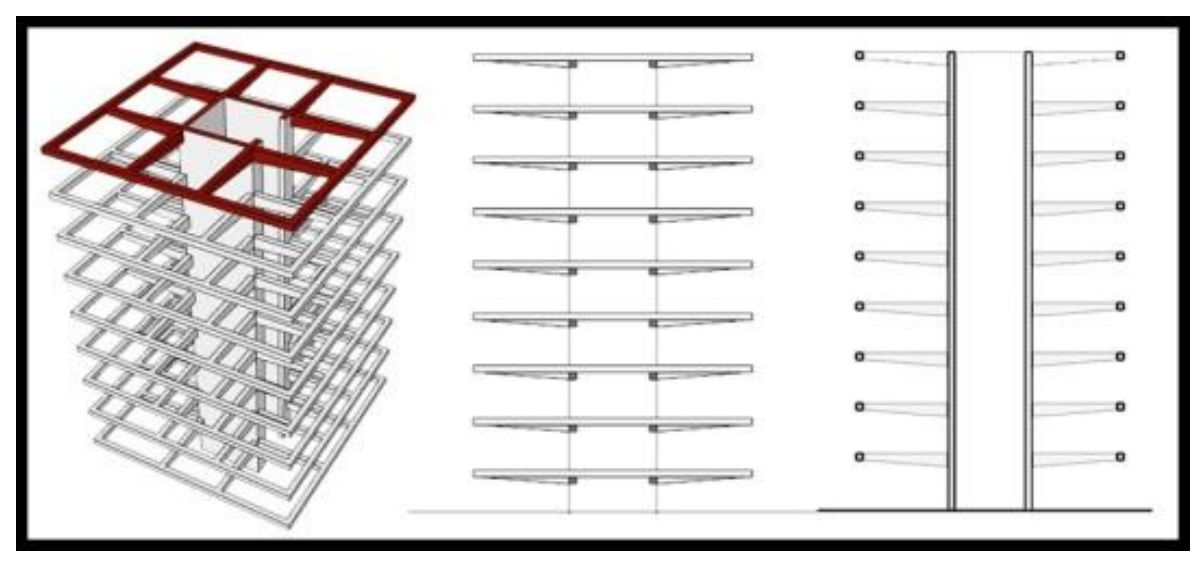

Şekil 2: Çekirdek Sistemler Perspektif, Görünüş ve Kesiti

\subsection{Kirişsiz Döşemeli Sistemler}

Kirişsiz döşemeli sistemlerde amaç, katlarda maksimum iç yükseklik ve kirişsiz düz bir tavan elde edebilmektir. Ancak, döşemenin kolonlar ile birleştiği noktada oluşan kesme kuvvetinin zımbalama etkisini ortadan kaldırabilmek için kolon başlıkları kullanılabilmektedir. Kirişsiz döşeme sistemleri, yanal yükler karşısında her zaman yeterli rijitliği sağlayamayabilir. Bu nedenle, perde duvar sistemleri ile gerekli desteklemeler sağlanabilmektedir.

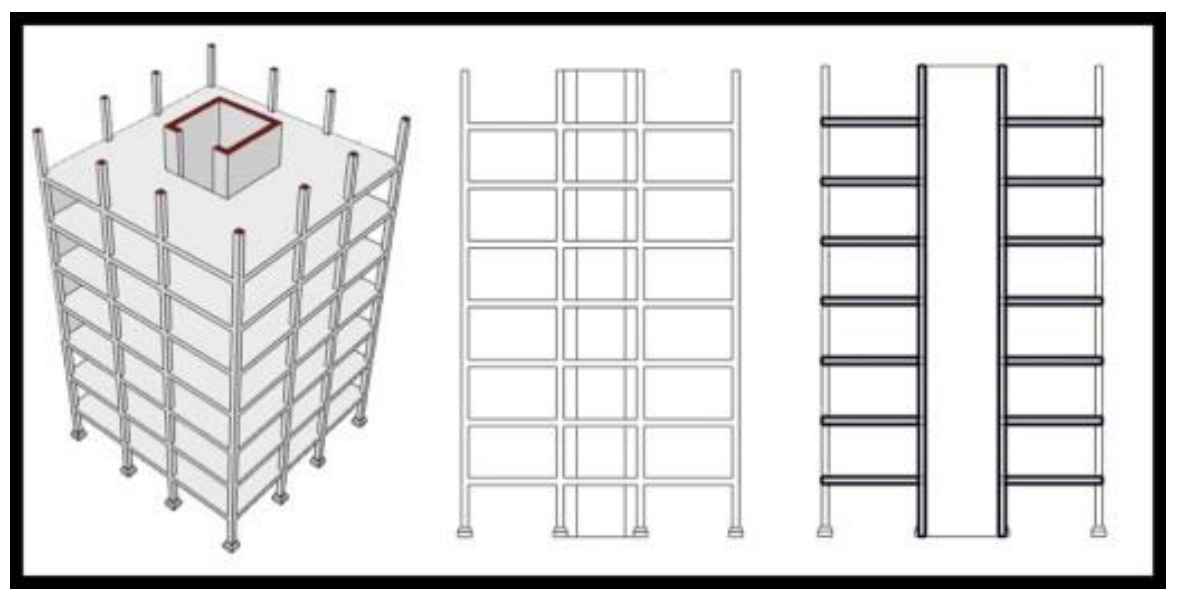

Şekil 3: Kirişsiz Döşemeli Sistemler Perspektif, Görünüş ve Kesiti 


\subsection{Perde Duvarlı Sistemler}

Perde duvarlı sistemler, çok katlı binalarda kullanılan perde duvarlar, temelden itibaren düşey bir konsol gibi tanımlanabilir. Tanımlanabilecek bu konsolun üzerinde bulunan katlar arasındaki yanal öteleme, yapının üst katlarına çıkıldıkça artış eğilimi göstermektedir. Dolayısıyla, bu sistemde yanal yüklerden oluşacak moment, kesme kuvvetleri ve bunların sebep olabileceği yanal ötelemeler dikkatle izlenmelidir. Çok katlı binaların ofis olarak kullanılması durumunda, sirkülasyon ve servis alanlarının çevresi yeterli büyüklükte perdeler ile kapatılabilmekte ve istenilen ölçüde çekirdekler oluşturulabilmektedir. Yapının konut olarak tasarlanması durumunda ise, söz konusu alanlar daha küçük olarak oluşturulabilmektedir.

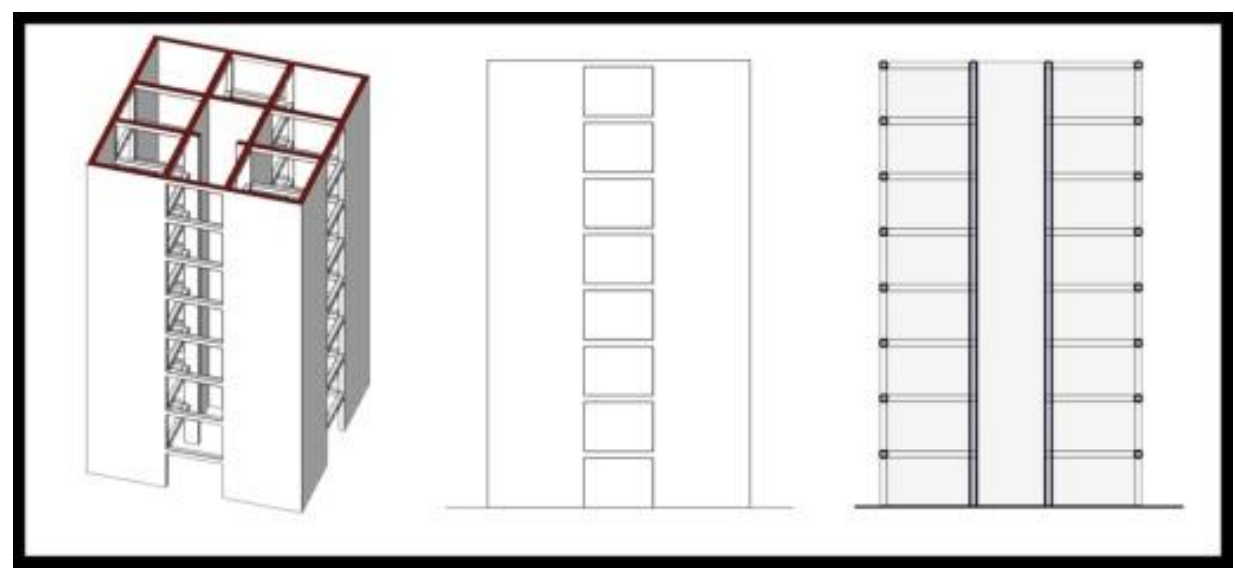

Şekil 4: Perde Duvarll Sistemler Perspektif, Görünüş ve Kesiti

\subsection{Kafes Perdeli Çerçeve ve Perde Duvarlı Çerçeve Sistemler}

Otuz katın üzerindeki çok katlı binalarda, kolonlar üzerinde meydana gelen eğilme, büyük deformasyonlara sebep olabilir. Bu durum, rijit çerçeve sistemler açısından değerlendirildiğinde, sistem yanal yükler karşısında yeterli performansı gösteremez. Kafes perdeli çerçeve ve perde duvarlı çerçeve sistemler ile rijit çerçeve sistem güçlendirilir ve bu sayede yapının toplam rijitliği arttırılabilmiş olunur.

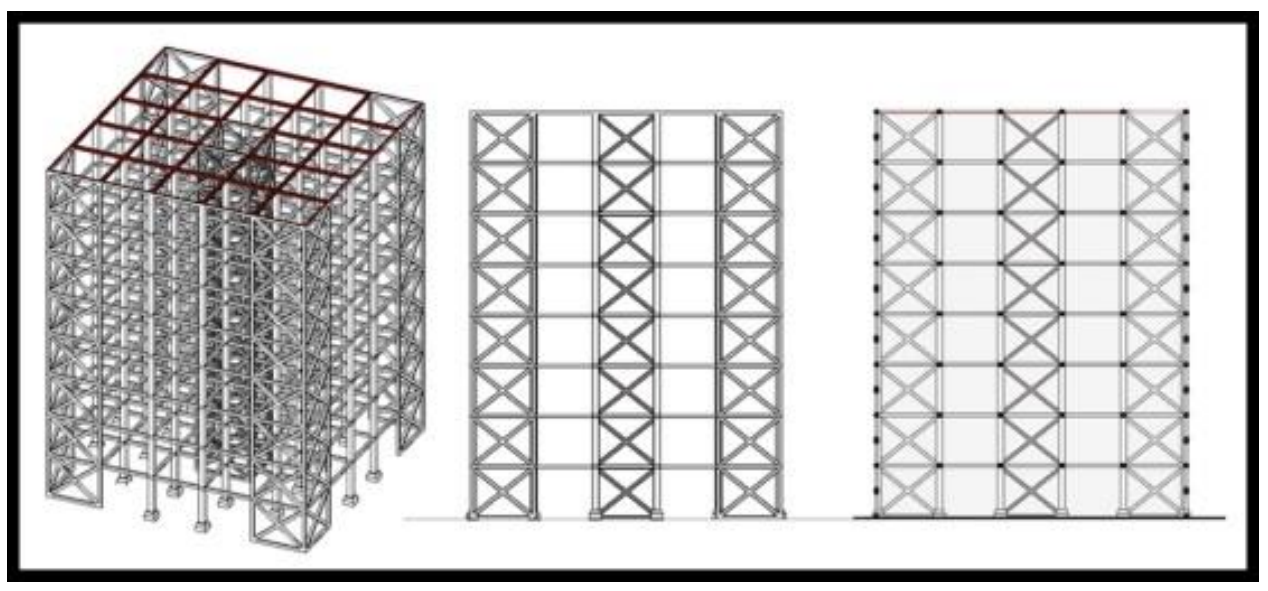

Şekil 5: Kafes Perdeli Çerçeve Sistemler Perspektif, Görünüş ve Kesiti

\subsection{Mega Kolon ve Mega Çekirdek Sistemler}

Mega kolon sistemler, yüzey kesit alanları çok büyük olan, düşey ve yanal yüklerin tamamını taşıyan mega kolonların olduğu sistemlerdir. Mega çekirdek sistemler ise, kesit yüzey alanları normalden çok büyük olan düşey ve yanal yüklerin tamamını taşıyan, perde duvarların oluşturduğu, mega çekirdeklerden oluşmaktadır. 


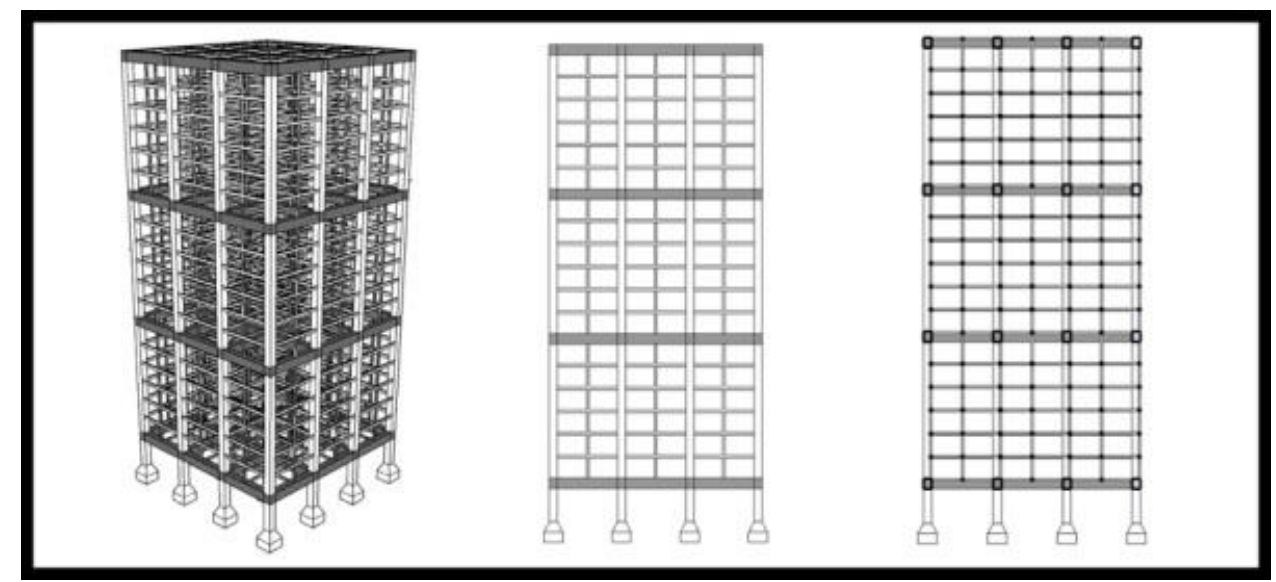

Şekil 6: Mega Kolon Sistemler Perspektif, Görünüş ve Kesiti

\subsection{Yatay Perdeli Çerçeve Sistemler}

Yatay perdeli çerçeve sistemler, yapıya ait kolonların ve çekirdeğin yatayda uzanan perdeler kullanılarak birbirine bağlandığı, bu sayede çekirdeğin yanal kuvvetler altında kolonlardan destek almasının sağlandığı ve yapının yanal ötelenmesinin azaltılarak sistemin rijitliğinin arttırılmak istendiği sistemlerdir.

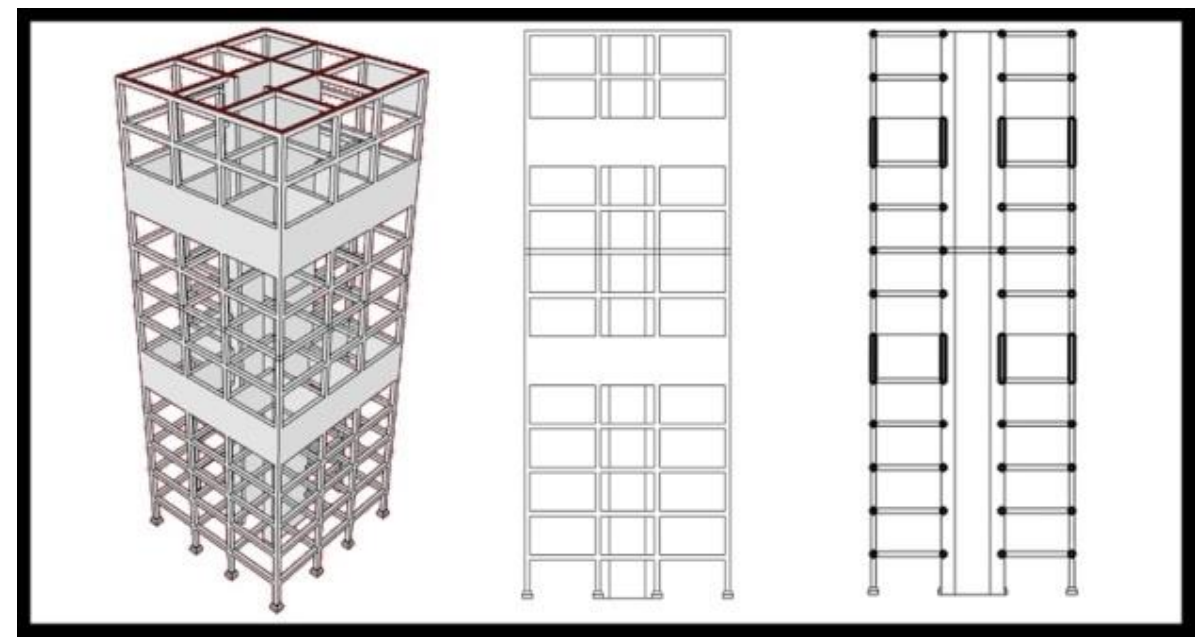

Şekil 7: Yatay Perdeli Çerçeve Sistemler Perspektif, Görünüşve Kesit

\subsection{Tüp Sistemler}

Tüp sistemler; çerçeve tüp sistemler, kafes tüp sistemler ve demet tüp sistemler olarak üç temel başlık altında değerlendirilebilir. Çerçeve tüp sistemler, rijit çerçeve sistemlere benzerlik göstermektedir. Bu sistemler, kolon sayısının arttırılarak kolon aralığının azaltıldığı, buna bağlı olarak kiriş yüksekliklerinin arttırıldığı ve kolonların birbirilerine derin kirişlerle bağlandığı rijitliği arttırılmış sistemlerdir.

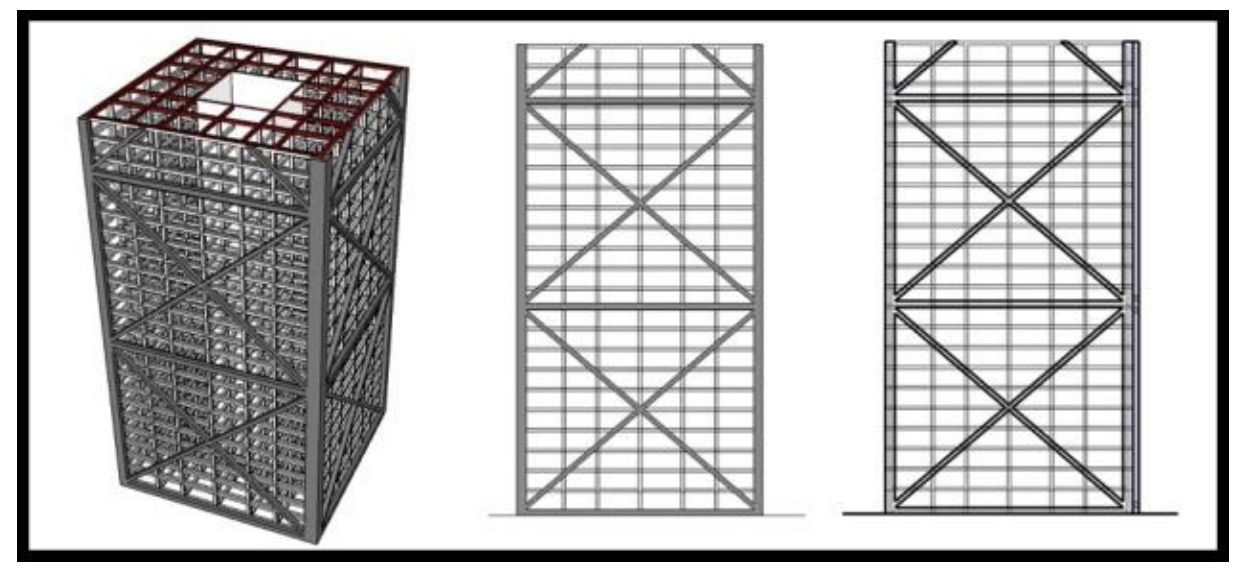

Şekil 8: Kafes Tüp Sistemler Perspektif, Görünüş ve Kesiti 
Çerçeve tüp sistemde kullanılan kolonların aralıklarının sık olması, özellikle zemin katlarda istenilen mimari nitelikleri taşıyan mekânların oluşturulmasında problemler doğurabilmektedir. Amaçlanan rijitlik azaltılmadan, kolon aralıklarının arttırılabilmesi için, çerçeve tüp sistem olarak tasarlanan yapının dış yüzeyinde çapraz destekleyici elemanların yerleştirilmesi sayesinde kafes tüp sistemler oluşturulmuştur.

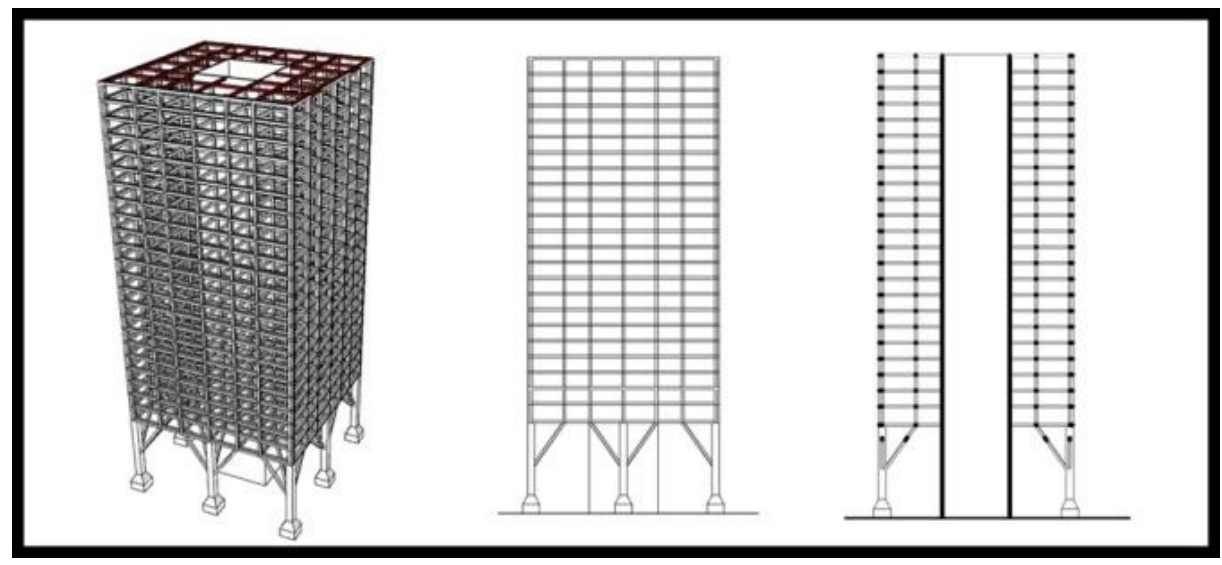

Şekil 9: Çerçeve Tüp Sistemler Perspektif, Görünüs ve Kesiti

Demet tüp sistemler, kafes tüp sistemlere oranla çok daha fazla kolon açıklığına ihtiyaç duyulduğu ve mimari tasarıma özgürlük sağlaması açısından çerçeve tüp ve kafes tüp sistemlerinin birlikte kullanıldığı bir sistem yapısına sahiptir. Bu sistemler, söz konusu tüp sisteminin istenilen kat/yükseklikte başlanabilmesi veya sonlandırılabilmesi sayesinde, kat planlarında ve hacimlerinde, mimarlara özgün tasarımlar yapabilme olanağı sağlayabilen sistemlerdir.

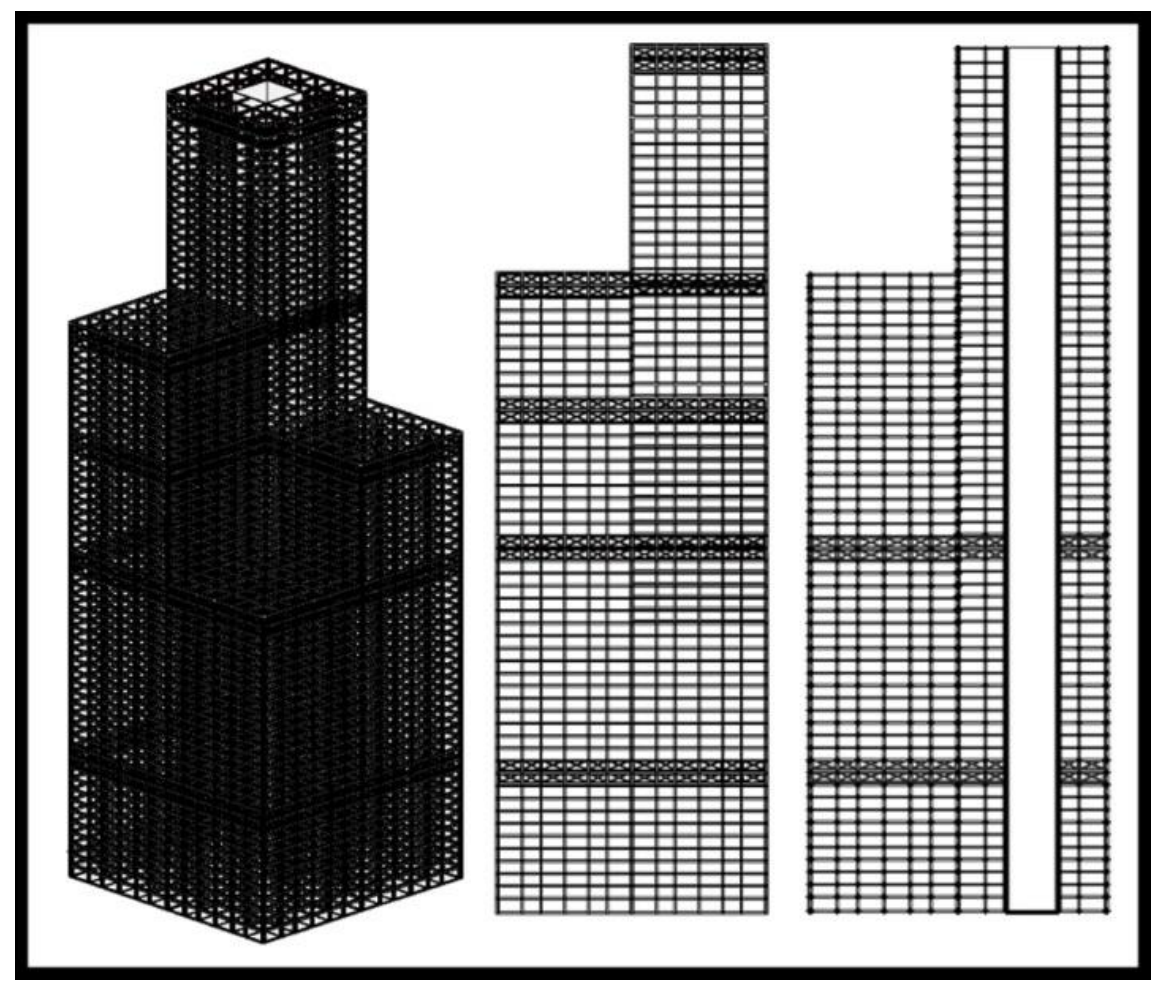

Şekil 10: Demet Tüp Sistemler Perspektif, Görünüşv Kesiti

\subsection{Karma Sistemler}

Yapı analizleri için kullanılan bilgisayar sistemlerindeki gelişmeler, mühendislerin yapının projesinin tasarımı sırasında çok sayıda farklı modeli hızlı bir şekilde ve alternatifli olarak inceleyebilmesine imkân vermektedir. Bu durum, çelik ve beton gibi çok katlı bina yapımında kullanılan iki önemli malzemenin çeşitli şekillerde birlikte kullanılabilmesini ve bu birlikteliğe ait bilgisayar analizlerinin sağlıklı şekilde yapılabilmesini sağlayabilmektedir. Bu avantaj, sadece malzeme kullanımında değil, çok katlı yapılarda kullanılan taşıyıcı sistemlerin karma-hibrit olarak kullanımları durumunda da sağlıklı analiz ve değerlendirme yapabilmeye imkân sağlamaktadır. Bu sayede, karma sistemler kullanılarak çok katlı yapılar inşa edilebilmektedir. Seattle'da bulunan Two Union Square ve Columbia Seafirst Center, New York'da bulunan Citycorp Center, Minneapolis'te bulunan First Bank Place ve Singapore' da bulunan Overseas Union yapıları bu sisteme verilebilecek örnekler olarak sayılabilir. 
Çok katlı yapılarda kullanılan taşıyıcı sistemlere genel olarak bakıldığında, çelik ve beton olmak üzere iki ana malzemenin kullanıldığı; özel uygulamalarda ise kompozit elemanların tercih edildiği görülebilmektedir. Çerçeve sistemler, çelik ve betonarme malzeme kullanılarak üretilebilmekte, genelde 30 kat, diğer sistemlerle karma olarak kullanılması durumunda ise 40-50 kata kadar yapı yüksekliklerine ulaşabilmektedir. Çekirdek sistem sadece betonarme olarak yapılabilmekte ve kat yüksekliği 20 kata kadar ulaşabilmektedir. Fakat çekirdek ve yanal sarmalı sistem kullanıldı̆̆ında beton ve çelik malzeme birlikte kullanılabilmekte ve kat adedi 35-40 kata kadar ulaşabilmektedir. Kirişsiz döşemeli sisteme bakıldığında, 20-25 kata kadar olan betonarme yapılarda kullanılabildiği görülebilmektedir. Perde Duvarlı Sistemler, betonarme olarak 30-35 kata kadar yapılabilmekte, diğer sistemlerle karma olarak kullanılması durumunda ise 40-45 kata kadar ulaşabilen bina yüksekliklerine imkân vermektedir. Kafes perdeli çerçeve ve perde duvarlı çerçeve sistemler, çelik, betonarme veya kompozit malzemeden yapılabilmektedir. Söz konusu bu uygulamalar sayesinde 40 kat ve üzeri kat adetlerine ulaşmak mümkün olabilmektedir. Betonarme ve kompozit malzemeler kullanılarak üretilen mega kolon ve mega çekirdek sistemler, çok katlı yapılarda 50 kat ve üzeri kat adetlerine ulaşabilmek için kullanılmaktadır.

Yatay perdeli çerçeve sistemler, betonarme, çelik ve kompozit olarak, 55 kat ve üzeri kat adetlerinin yapımında kullanılmaktadır. Tüp sistemler ise betonarme, çelik ve kompozit olarak üretilebilmektedir. Chicago'daki John Hancock Center (kafes tüp, 100 kat) ve SearsTower (demet tüp, 110 kat) veya New York'daki World Trade Center (çerçeve tüp, 110 kat) örneklerine bakıldığında kat yüksekliklerinin 100 kat ve üzeri olduğu görülebilmekle birlikte söz konusu sistemlerin 45 kat ve üzeri kat adetlerinde uygulanması avantajlı olabilmektedir. Karma sistemler, karma olarak birlikte kullanılması düşünülen taşıyıcı sistemlerin özelliklerine bağlı olarak betonarme, çelik ve kompozit olarak çeşitlenebilmekte, kat yüksekliği ise yine birlikte kullanılan sistemlerin karakteristik özelliklerine bağlı olarak değişkenlik gösterebilmektedir.

\section{3. Çok Katlı Yapılarda Kullanılan Betonarme Döşeme Sistemleri}

\subsection{Kirişsiz Döşeme Sistemleri}

Kirişsiz döşeme sistemleri, mimari tasarımda, tasarımcılara kolaylıklar sağlamaktadır. Bu sistem, yapısında kiriş vb. engeller bulundurmamasından dolayı, iklimlendirme ve diğer tesisat sistemlerinin düzenlenmesi için elverişlidir. Döşemeden sarkan kiriş bulunmamasından dolayı, elde etmek istenilen kat yüksekliği kiriş sarkma mesafesi göz ardı edilerek sağlanabilir. Bununla birlikte, döşemenin kalınlığ 1 ve buna bağlı olarak ağırlığ oldukça fazladır. Kirişsiz döşeme sistemleri, plak döşeme sistemleri ve mantar döşeme sistemleri olarak iki temel başlık altında değerlendirilebilir.

Plak döşeme sistemleri, döșeme açıklığ arasında olabilen ve 8-12 metre arasındaki açıklıkların geçilebildiği döşeme sistemleridir. Sistem, kolon ve/veya perde kolonlara oturmaktadır. Sistemin kolonlara oturduğu noktalarda kesme kuvveti gerilmeleri oluşmakta, buna bağlı olarak zımbalama etkisi doğabilmekte ve bu duruma karşı tedbir alınması gerekmektedir.

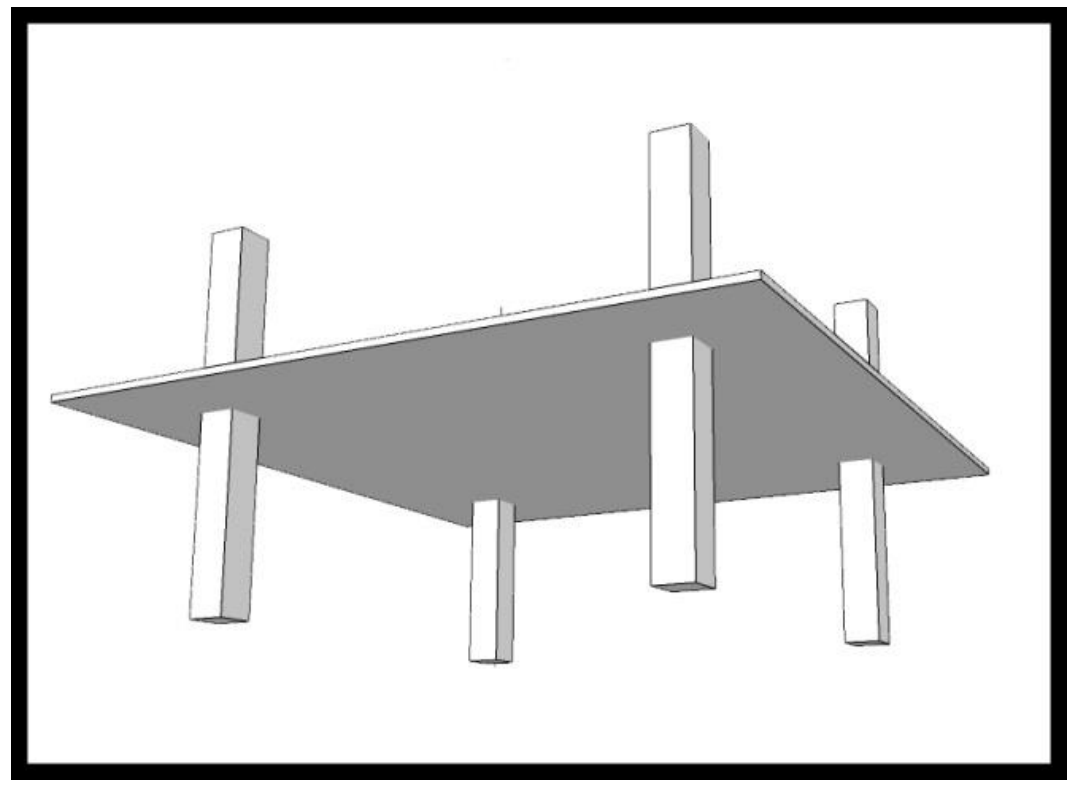

Şekil 11: Plak Döşeme Sistemleri Perspektif

Mantar döşeme sistemleri, plak döşeme sistemlerine oranla daha masraflıdır fakat daha geniş açıklıklar geçilebilmektedir. Geçilmek istenen açıklık arttıkça, söz konusu kesme kuvvetleri ve buna bağlı olarak zımbalama etkisi artacağından, kolonların başları büyütülerek mantar şekli kazandırılır ve döşemeye temas ettikleri yüzey alanı genişletilerek zımbalama etkisine karşı koyması planlanır. 


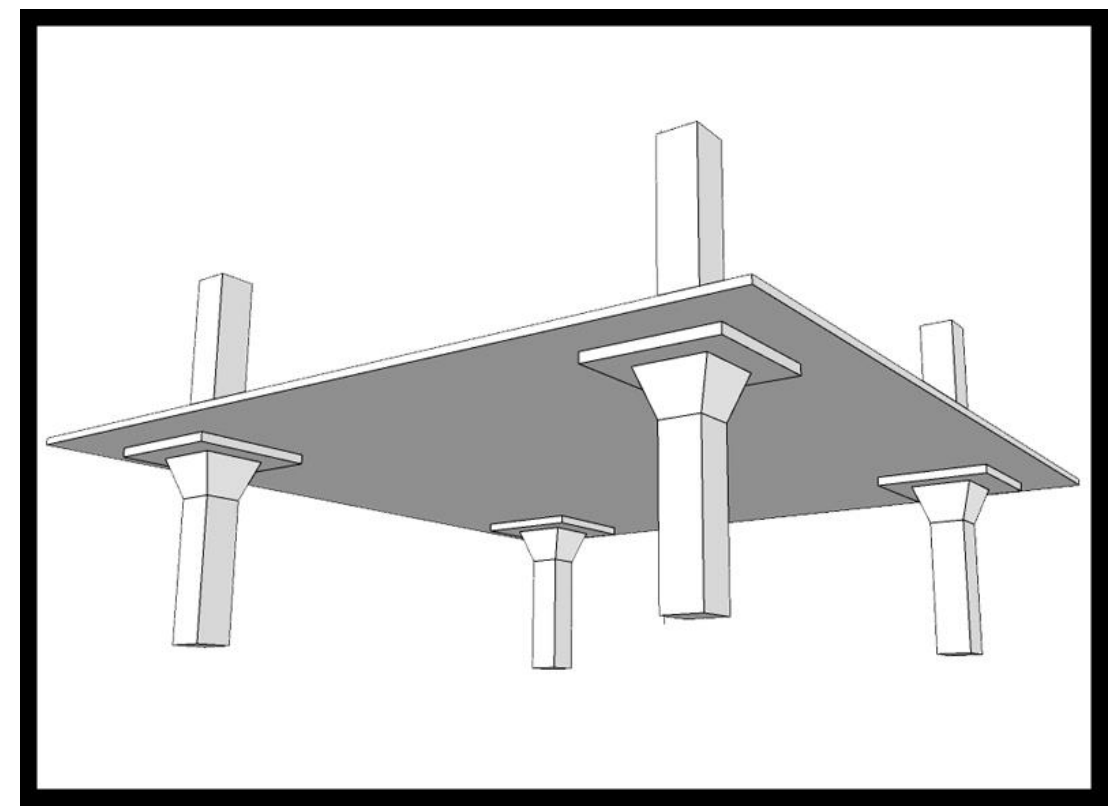

Şekil 12: Mantar Döşeme Sistemleri Perspektif

\subsection{Nervürlü Döşeme Sistemleri}

Dişli döşeme olarak da adlandırılan bu döşeme sistemleri, istenilen döşeme açıklığının geçilebilmesi, plak kalınlığının ve ağırlığının azaltılabilmesi için nervürler yapılarak dişli bir formda oluşturulur. Bu nervürler, kendi eksenlerine dik olacak şekilde yerleştirilmiş olan ana döşeme kirişlerine bağlanırlar. Nervür kirişleri 10-20 cm eninde ve 20-60 cm yüksekliğinde olabilmekte, en az $10 \mathrm{~cm}$ kalınlığa sahip bir plak ile üst noktalarından birbirlerine bağlanmakta ve bu kirişler ile 10-12 metre döşeme açıklıkları geçilebilmektedir. Nervürlü döşeme sistemleri, nervürlere paralel ve nervürlere dik olan iki yöndeki yanal kuvvetlere karşı aynı performansı gösteremediğinden, yanal kuvvetlerin önemli olduğu durumlarda titizlikle hesaplanmalı veya tercih edilmemelidir.

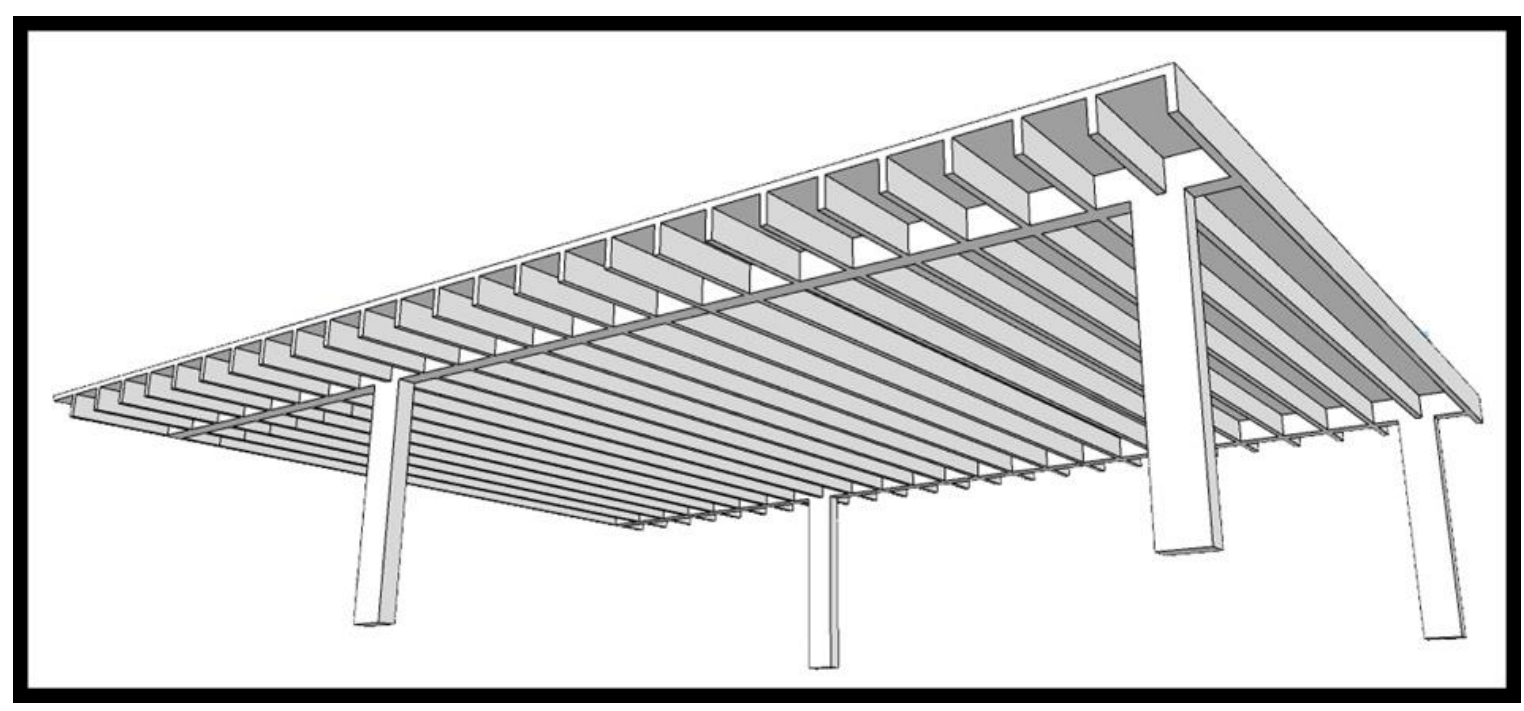

Şekil 13: Nervürlü Döşeme Sistemleri Perspektif

\subsection{Kaset Döşeme Sistemleri}

Kaset döşeme sistemleri, ağırlığı oldukça fazla olmasına rağmen uzun açıklıkların geçilebilmesi için oldukça elverişlidirler. Bu döşeme sistemleri, nervürlü döşeme sistemlerinde olduğu gibi, dişli olacak şekilde, fakat dişlerin tek yönde değil, birbirine dik her iki yönde konumlandırılması ile elde edilir. Kolonların döşemeyle birleştiği noktalarda mantar döşeme sistemlerinde olduğu gibi, zımbalama etkisi söz konusu olabilir. Bu sebeple, söz konusu alandaki döşeme gövdesi doldurularak bu durumun önüne geçilebilir. 


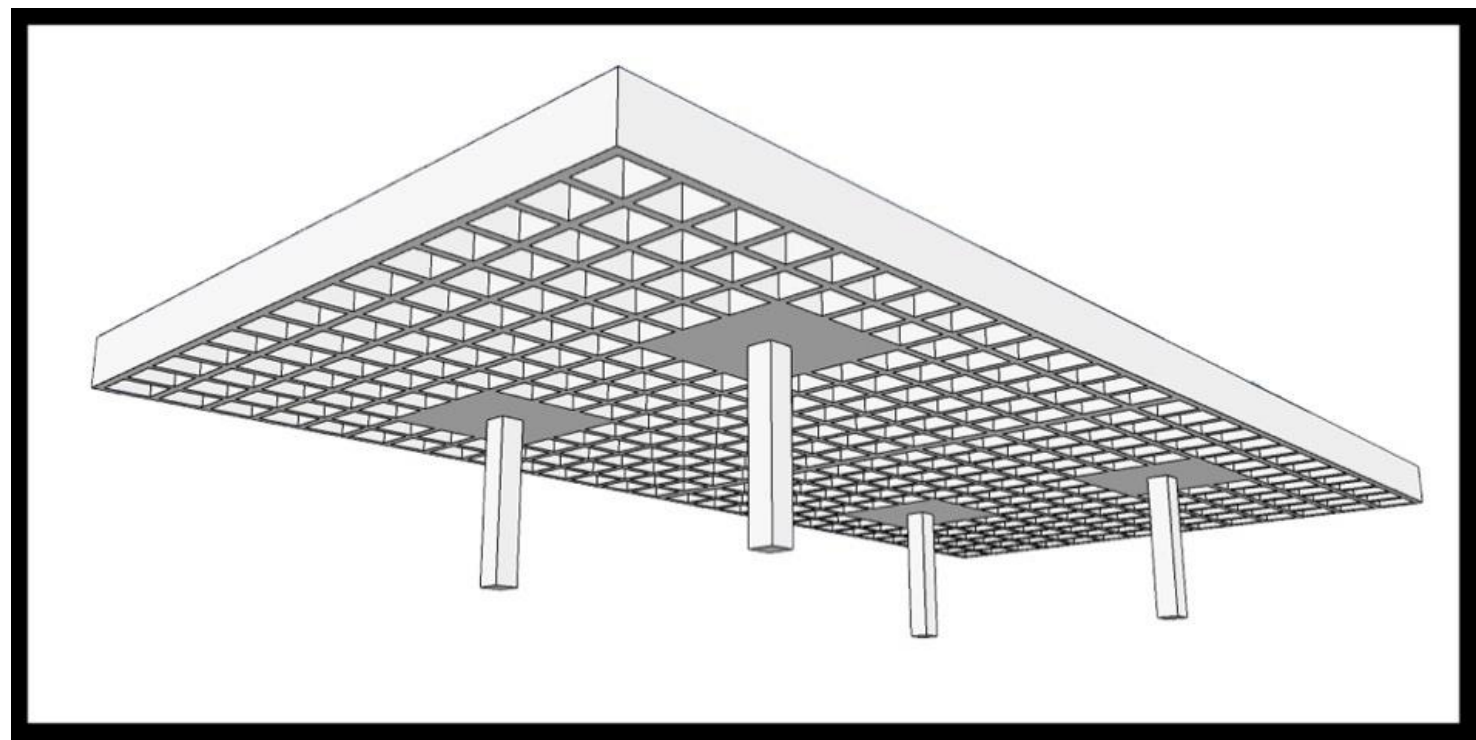

Şekil 14: Kaset Döşeme Sistemleri Perspektif

\subsection{Kirişli Döşeme Sistemleri}

Kirişli Döşeme Sistemleri; döşeme plağı ve ve kirişin bir tür rijit çerçeve kirişi gibi birlikte çalıştırılması ile oluşturulur (Sağlam, 2016). Kirişli döşeme sistemleri, Tek doğrultuda kirişli döşeme sistemleri, İki doğrultuda kirişli döşeme sistemleri ve 1zgara kirişli döşeme sistemleri olarak üç temel başlık altında değerlendirilebilir.

Tek doğrultuda kirişli döşeme sistemleri, aynı istikamette paralel veya radyal kirişleri birleştiren 15 - $20 \mathrm{~cm}$ kalınlığında döşeme plaklarından oluşur. Tek doğrultulu kirişli sistem sayesinde yaklaşık 6 metrelik açıklığı tek plakla geçebiliriz. Tipik bina planında, merkezde çekirdek ve etrafındaki kolonlarının ise çekirdeğe yakın olması durumunda rahatlıkla kullanılabilir. Kirişlerin yüksekliğgi mesnet açıklığının yaklaşık 1/15- 1/20' sinden az olmamalıdır. Bu döşemelerde, esas donatı kısa doğrultuya paralel olarak yerleştirilmeli bu donatılar kesitin altında, bir düz ve bir pilye olarak düzenlenmelidir. Uzun doğrultuya ise dağıtma donatısı yerleştirilmelidir. Dağıtma donatısı sadece düz olarak gene kesitin altına fakat alttaki esas donatının üstüne gelecek şekilde düzenlenmelidir.

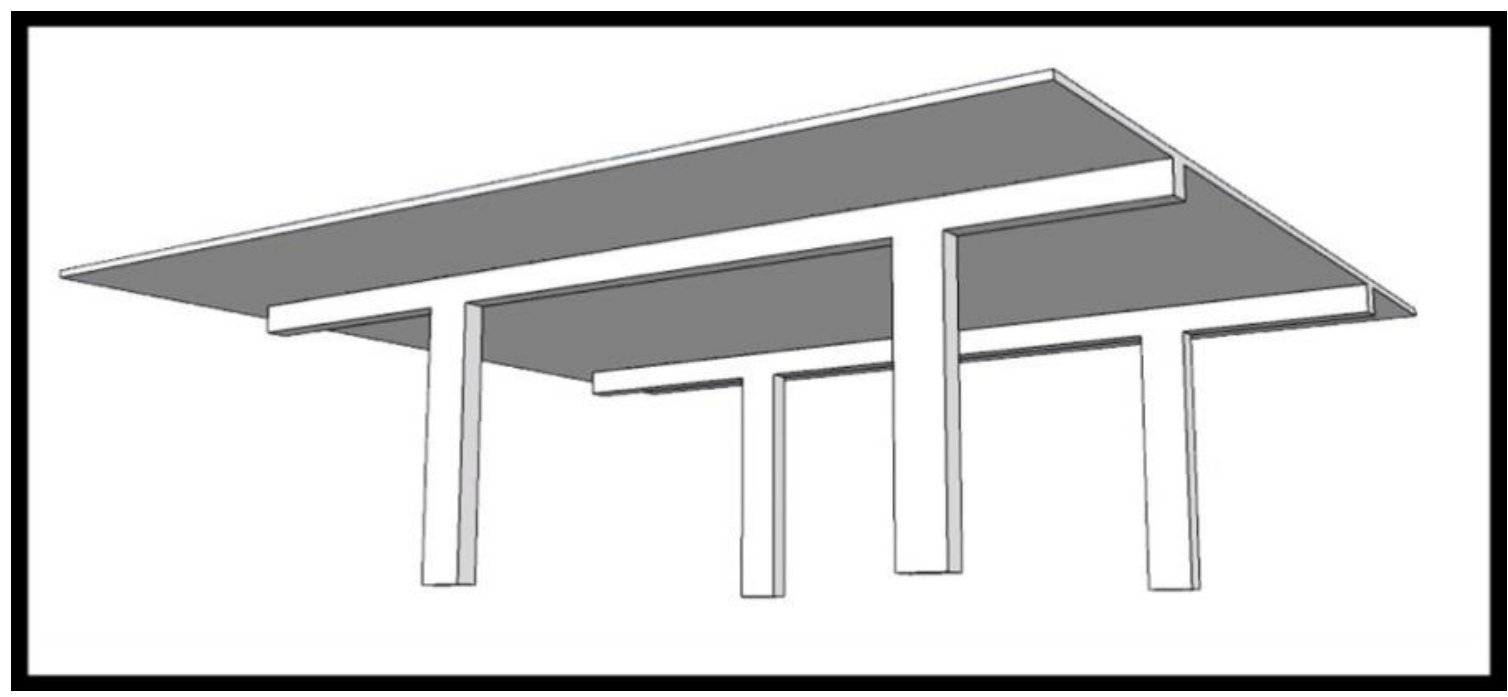

Şekil 15: Tek Doğrultuda Kirişli Döşeme Sistemleri Perspektif

İki doğrultuda kirişli döşeme sistemleri; kısa açıklık doğrultusunda en az iki döşemenin bulunması halidir. Bu tip döşeme ise 10$15 \mathrm{~cm}$ kalınlığında bir plakadan oluşup ayrı iki doğrultudaki ana kirişler üzerine basmasıyla oluşur. Kirişlerin yükseklikleri, kolonların birbirine olan uzaklıkları ayrıca üzerindeki hareketli yüklerle doğru orantılıdır. Son germeli sistem kullanılması dahilinde kiriş yüksekliği büyük oranda kısaltılabilir. Bu döşeme tipi bize yaklaşık 8 metreye kadar açıklık geçme imkânı tanımaktadır. Bu sistemde açıklıkların birbirinden fazla farklı olmadığı veya daha kesin hesabın gerekli olmadığ durumlarda bu yöntem kullanılabilir. Moment hesaplarında negatif moment için plak mesnedi iç, yüzü düzlemindeki kesit, pozitif moment için ise plak açıklık ortasındaki kesit esas alınır. 


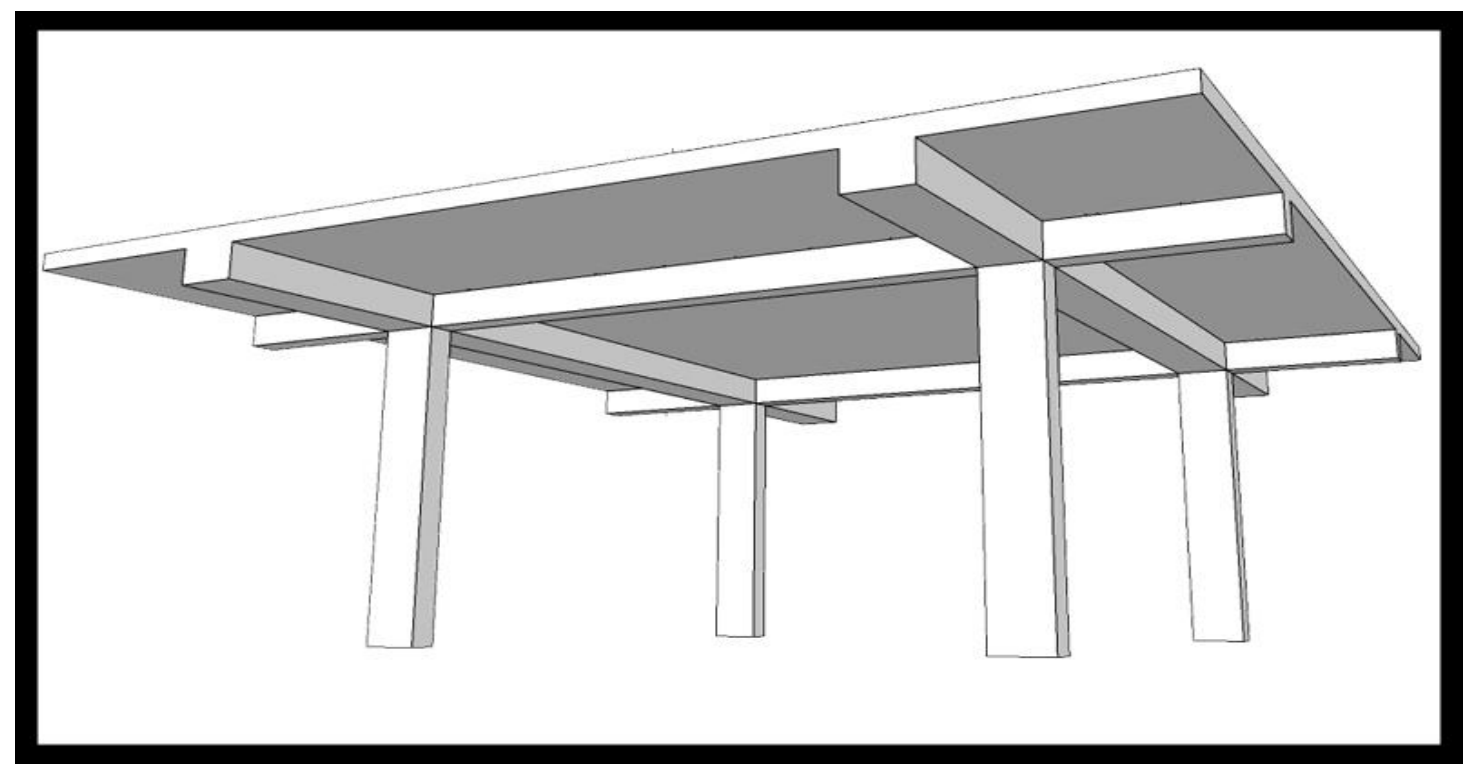

Şekil 16: İki Doğrultuda Kirişli Döşeme Sistemleri Perspektif

Izgara kirişli döşeme sistemleri ile kolon aksları arasındaki mesafe fazlaysa ve yapının kullanımı dahilinde taşınacak yükler ağır ise kolon akslarındaki kirişlere ek olarak her iki doğrultuda ara kirişler eklenerek açıklıklar rahatlıkla geçilebilir. Döşeme planının şeklinden dolayı 1zgara kirişli döşeme ismini almıştır. Kolonların formlarına göre, dikdörtgen ya da kare döşeme düzenini oluştururlar. Sistemin getirdiği önemli bir diğer özellik ise, yaklaşık 15 metreye kadar açıklık geçme imkanı tanımasıdır. Tali kirişler arasındaki mesafe azaltılarak döşemedeki diğer kirişlerin yükseklikleri istenilen boyutta değiştirilebilir. Statik açıdan kaset döşemeyle benzerlik gösterir. Yapıda ihtiyaç duyulan irili ufaklı bütün boşluklar için ideal bir yapıya sahiptir.

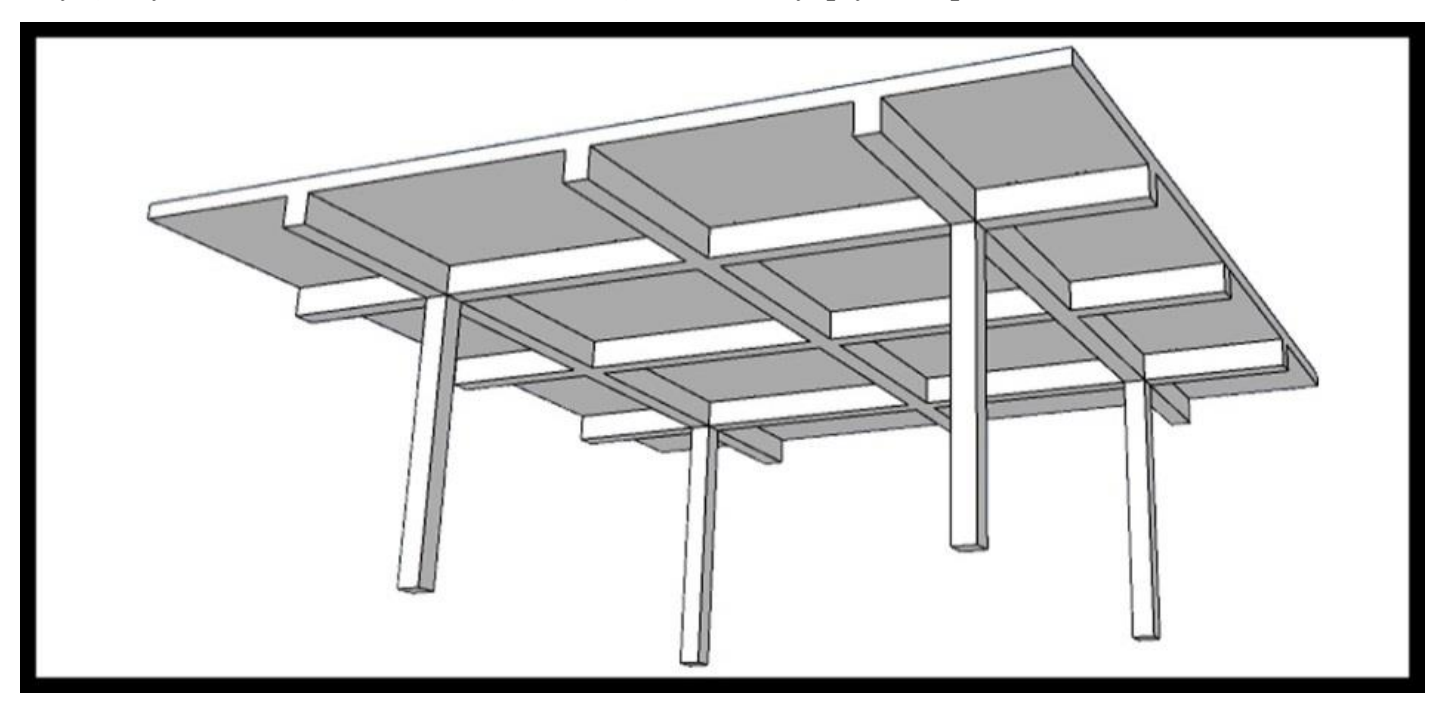

Şekil 17: Izgara Kirişli Döşeme Sistemleri Perspektif

\section{5. Ön Germeli Döşeme Sistemleri}

Ön germeli döşeme sistemleri, diğer adıyla precast sistemler 1960' lı yıllarda kullanılmaya başlanmıştır. Beton plakta ön germeli basınç gerilmeleri meydana getirilerek, betonun çekme gerilme kuvvetlerine maruz kalmasını engellemek amaçlanmaktadır. Bu sayede, çok daha narin kesitlerin dizaynına olanak tanınabilmektedir. Alışveriş merkezleri ve otoparklarda yaygın olarak kullanılmaktadır. Boşluklu döşemelerde ön germe işlemi, tutucu kafalar arasında gerdirilen ön germe tellerinin bulunduğu döşeme bandına gezici makineyle betonun dökülüp sıkıştırılması ve beton belli bir mukavemete ulaştıktan sonra tellerin bağlantılardan kurtarılması ile uygulanır. Böylece teller ve beton arasındaki aderans sayesinde kuvvet betona aktarılır. Transfer aşamasında çelik ve beton arasında gerilme dengesi sağlanır. 


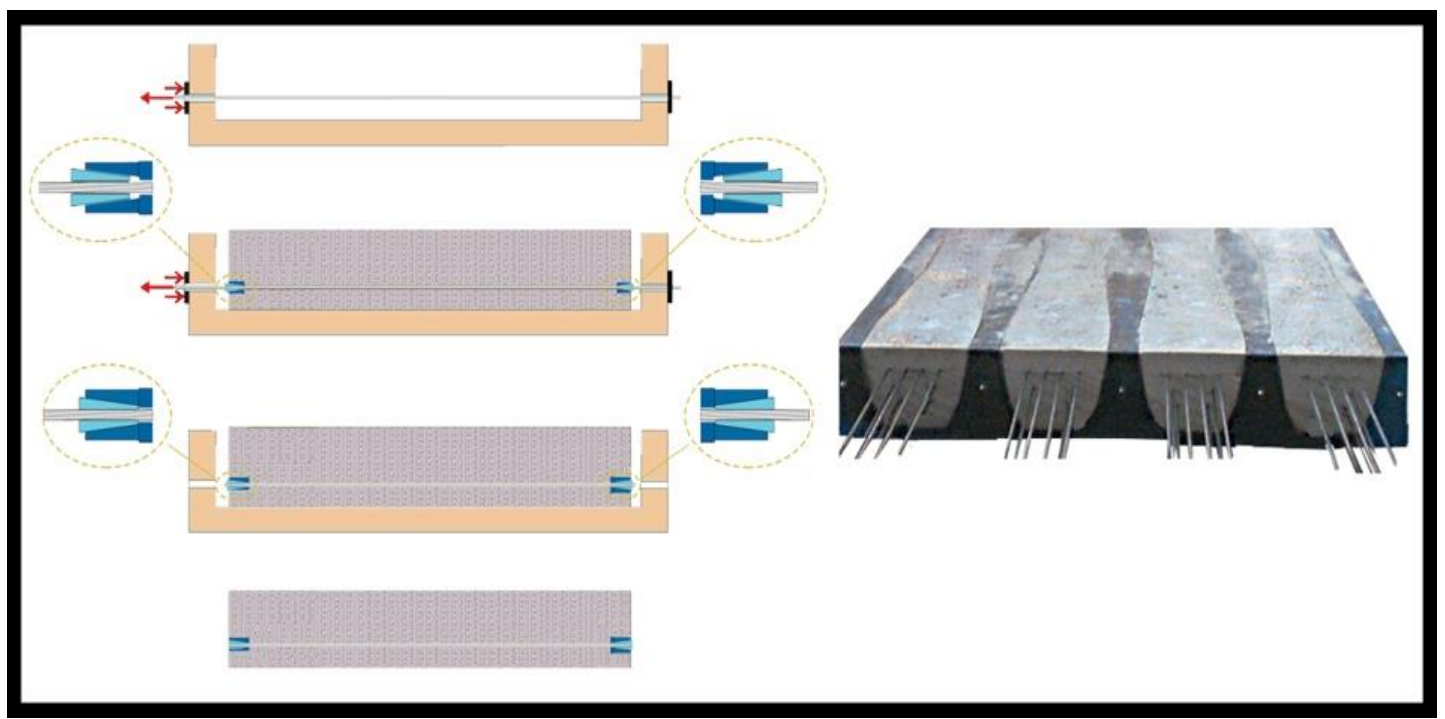

Şekil 18: Ön Germeli Döşeme Sistemleri Perspektif

\subsection{Ard Germeli Döşeme Sistemleri}

Ard germe, betonu çekme kuvvetlerine karşı kuvvetlendirmek için kullanılan yüksek dayanımlı çelik halatların, beton dökümü işleminden sonra gerilmesi yöntemidir. Yapı inşa alanında üretilen ard germe döşeme sistemleri, 1980'li yıllardan itibaren çok katlı, özellikle ofis amaçlı kullanılan binalarda görülmektedir. Bu sistemler, içerisindeki yuvalarında bulunan 12,7 ya da 15,2 milimetrelik ileri seviyede çelik tendonlar barındırır. Kirişlerin zamanla sarkmasını engellemek istenilirse, kirişsiz döşeme sistemi mevcutsa döşemenin kalınlığını azaltmak için ard germe yöntemi kullanılır. Ard germe, köprülerde çok büyük açıklıkların geçilmesini ve kiriş sürekliliği sağlar. Ard germe işlem sırası şu şekildedir; beton dökülmeden önce donatıların içine koruyucu kılıflar yerleştirilir. Beton dökülmesinden sonra, ard germe halatları koruyucu kılıfların içerisine sürülür. Hidrolik krikolar kullanılarak, proje aşamasında hesaplanan basınç kuvvetleri altında çelik halatlar gerilir. Gerilme işleminin ardından ard germe halatları kesilir. Kılıflara daha önce yerleştirilen hortumlardan özel çimento şerbeti (grout) basınçla yerleştirilir.

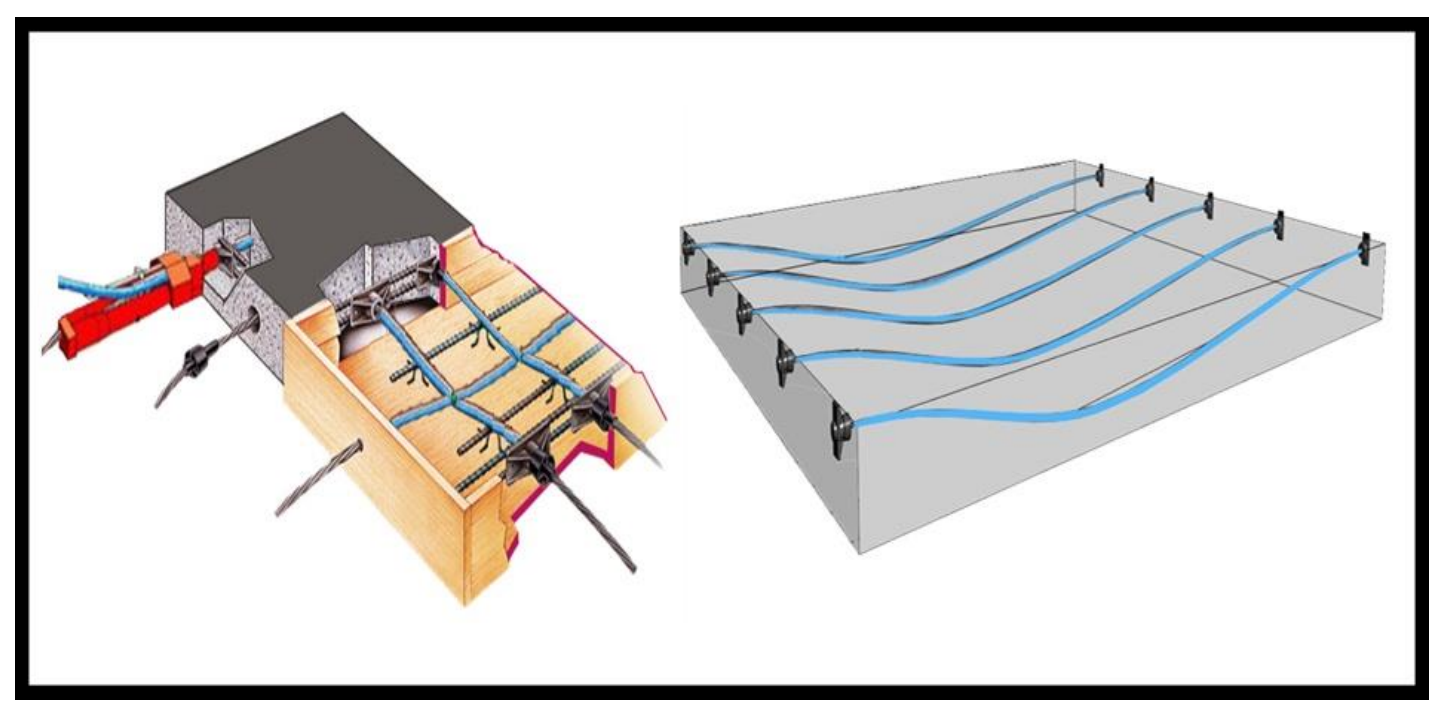

Şekil 19: Ard Germeli Döşeme Sistemleri Perspektif

\section{4. İstanbul'daki Çok Katlı Yapıların Betonarme Döşeme Sistemleri}

İstanbul, çok katlı yapıların yoğunlukla görüldüğü şehirlerden biridir. Araştırma kapsamında, İstanbul'da bulunan, 1992 ile 2010 yılları arasında tamamlanmış, yirmi beş adet çok katlı yapı seçilmiştir. Söz konusu yapılar, toplam yapı yüksekliği, kat adedi, yapı fonksiyonu, taşıyıcı sistem cinsi, kullanılan temel cinsi ve kalınlığı, kat yüksekliği, kiriş açıklığı, kalınlığı ve malzeme cinsi, kolon açıklığı ve malzeme cinsi başlıkları üzerinden incelenmiş, bu veriler Tablo 1'de tablolaştırılmıştır. Bu veriler incelendiğinde, rastgele seçilmiş bu yirmi beş yapının, toplam yapı yüksekliklerinin 90 ile 261 metre arasında değiştiği ve ortalama yapı yüksekliğinin 131 
metre olduğu görülmektedir. Kat adetlerinin 27 ile 64 adet arasında değişkenlik gösterdiği, ortalamada ise 34,24 adet olduğu, bu kat adetlerinin 1 ile 11 adet arasında bodrum kata sahip olduğu, ortalamada ise, 5,48 adet düzeyinde bulunduğu görülmektedir. Yapı fonksiyonu olarak, AVM, konut, otel ve ofis kullanımlarının mevcut olduğu, bununla birlikte, \%64 oranında ofis fonksiyonunun ağırlıklı olarak tercih edildiği görülmektedir. Tablo 1'e göre yapıların tamamına yakınında çekirdek ve çerçeve tüp / kolon sistemin kullanıldığı, \%96 oranında radye temel cinsinin tercih edildiği ve temel kalınlı̆̆ olarak 150 ile $300 \mathrm{~cm}$ arasında değişkenlik gösterdiği, ortalamada ise, $240 \mathrm{~cm}$ olduğu görülmektedir. Kat yüksekliklerinin 300 ile $500 \mathrm{~cm}$ aralığında bulunduğu, ve ortalamada $368 \mathrm{~cm}$ olduğu görülebilmektedir. Kiriş açıklıklarının $600 \mathrm{~cm}$ ile $900 \mathrm{~cm}$ arasında değişkenlik gösterdiği ve ortalamada ise, $790 \mathrm{~cm}$ olduğu görülmektedir. Kiriş kalınlıklarının ise, $32 \mathrm{~cm}$ ile $110 \mathrm{~cm}$ arasında değişkenlik gösterdiği ve ortalamada ise $53,33 \mathrm{~cm}$ olduğu görülebilmektedir. Kolon açıklıklarının, $300 \mathrm{~cm}$ ile $960 \mathrm{~cm}$ arasında değişkenlik gösterdiği ve ortalamada ise $710 \mathrm{~cm}$ olduğu görülmektedir.

Tablo 1. İstanbul'daki Çok Katlı Yapıların Taşlyııı Sistem Özellikleri

\begin{tabular}{|c|c|c|c|c|c|c|c|c|c|c|c|c|}
\hline $\begin{array}{c}\text { Yapı İsmi } \\
\text { Tamamlanma Tarihi }\end{array}$ & $\begin{array}{c}\text { Yapı } \\
\text { Yük. (M) }\end{array}$ & Kat Adedi & $\begin{array}{c}\text { Yapı } \\
\text { Fonksiyonu }\end{array}$ & Taşıyıcı Sistem Cinsi & Temel Cinsi & $\begin{array}{c}\text { Temel } \\
\text { Kalınlı̆̆ı (M) }\end{array}$ & $\begin{array}{c}\text { Kat } \\
\text { Yüksekliği } \\
(\mathrm{cm})\end{array}$ & $\begin{array}{c}\text { Kiriş } \\
\text { Açıklı̆ı } \\
\text { (M) }\end{array}$ & $\begin{array}{c}\text { Kiriş } \\
\text { Kalınlığı } \\
(\mathrm{cm})\end{array}$ & $\begin{array}{c}\text { Kiriş } \\
\text { Malzemesi }\end{array}$ & $\begin{array}{c}\text { Kolon } \\
\text { Açıklığı } \\
\text { (M) }\end{array}$ & $\begin{array}{c}\text { Kolon } \\
\text { Malzemesi }\end{array}$ \\
\hline $\begin{array}{l}\text { İstanbul Sapphire } \\
\text { (2010) }\end{array}$ & 261 & $64(10)$ & AVM/Konut & Çekirdek + Çerçeve & $\begin{array}{c}\text { Betonarme } \\
\text { Radye }\end{array}$ & $1,5-3$ & 400 & 9 & 105 & Betonarme & 9 & Betonarme \\
\hline Iş Bankası Kule 1 (2000) & 181 & $52(5)$ & Ofis & $\begin{array}{c}\text { Çekirdek+Çevre } \\
\text { Tüp } \\
\end{array}$ & $\begin{array}{c}\text { Betonarme } \\
\text { Radye }\end{array}$ & 3 & 400 & 8 & 38 & Betonarme & 8 & Betonarme \\
\hline Şişli Plaza (2007) & 170 & $44(4)$ & Konut & $\begin{array}{c}\text { Çekirdek+Çevre } \\
\text { Tüp }\end{array}$ & $\begin{array}{l}\text { Betonarme } \\
\text { Radye }\end{array}$ & 3 & 350 & 8 & 60 & Betonarme & 8 & Betonarme \\
\hline $\begin{array}{l}\text { Selenium Twins Kule } 1 \\
\text { ve } 2(2010)\end{array}$ & 159 & $42(5)$ & Konut & $\begin{array}{l}\text { Çekirdek+Çevre } \\
\text { Kolon }\end{array}$ & $\begin{array}{c}\text { Betonarme } \\
\text { Radye }\end{array}$ & 2,2 & 350 & 8,5 & 40 & Betonarme & 8,5 & Betonarme \\
\hline $\begin{array}{l}\text { Koza Plaza Kule } 1 \text { ve } 2 \\
(2006)\end{array}$ & 152 & $44(4)$ & Ofis & $\begin{array}{c}\text { Çekirdek+Çevre } \\
\text { Kolon } \\
\end{array}$ & $\begin{array}{c}\text { Betonarme } \\
\text { Radye }\end{array}$ & 2,2 & 365 & - & - & Betonarme & 9 & Betonarme \\
\hline Metrocity B Blok (2003) & 135 & $27(5)$ & Konut & $\begin{array}{c}\text { Çekirdek+Çevre } \\
\text { Tüp }\end{array}$ & $\begin{array}{l}\text { Betonarme } \\
\text { Radye }\end{array}$ & 3 & 500 & 8 & 50 & Betonarme & 8 & Betonarme \\
\hline $\begin{array}{l}\text { Sabancı Center Kule } 2 \\
\text { (1993) }\end{array}$ & 142 & $39(5)$ & Ofis & $\begin{array}{c}\text { Çekirdek+Çevre } \\
\text { Kolon } \\
\end{array}$ & $\begin{array}{c}\text { Betonarme } \\
\text { Radye }\end{array}$ & 1,5 & 370 & 7,5 & 45 & Betonarme & 6 & Betonarme \\
\hline $\begin{array}{l}\text { Garanti Bankası } \\
\text { Merkezi(2002) }\end{array}$ & 141 & $21(7)$ & Ofis & $\begin{array}{c}\text { Çekirdek+Çevre } \\
\text { Kolon }\end{array}$ & $\begin{array}{c}\text { Betonarme } \\
\text { Radye }\end{array}$ & 2 & 450 & 9 & 50 & Betonarme & 9 & Betonarme \\
\hline Beybi Giz Plaza (1996) & 136 & $34(4)$ & Ofis & $\begin{array}{c}\text { Çekirdek+Çevre } \\
\text { Tüp }\end{array}$ & $\begin{array}{c}\text { Betonarme } \\
\text { Radye }\end{array}$ & 2 & 310 & 6 & 40 & Betonarme & 6 & Betonarme \\
\hline Süzer Plaza (2001) & 136 & $41(11)$ & $\begin{array}{c}\text { Konut/ } \\
\text { Ofis/Otel }\end{array}$ & $\begin{array}{l}\text { Çekirdek+Çevre } \\
\text { Kolon }\end{array}$ & $\begin{array}{c}\text { Betonarme } \\
\text { Radye }\end{array}$ & 2 & 400 & 6,5 & 40 & Betonarme & 6,5 & Betonarme \\
\hline Elit Residence (2001) & 133 & $40(5)$ & Konut & $\begin{array}{c}\text { Çekirdek+Çevre } \\
\text { Tüp } \\
\end{array}$ & $\begin{array}{l}\text { Betonarme } \\
\text { Radye }\end{array}$ & 3 & 350 & 8 & 40 & Betonarme & 8 & Betonarme \\
\hline $\begin{array}{l}\text { Astoria Kule } 1 \text { ve } 2 \\
(2007)\end{array}$ & 127 & $27(5)$ & $\begin{array}{l}\text { Konut/ } \\
\text { Ofis/Otel }\end{array}$ & $\begin{array}{l}\text { Çekirdek+Çevre } \\
\text { Kolon }\end{array}$ & $\begin{array}{l}\text { Betonarme } \\
\text { Radye }\end{array}$ & 2,5 & 415 & 8 & 50 & Betonarme & 8 & Betonarme \\
\hline $\begin{array}{l}\text { Yapı Kredi Merkez B. } \\
(1993)\end{array}$ & 120 & $30(7)$ & Ofis & $\begin{array}{c}\text { Çekirdek+Çevre } \\
\text { Tüp }\end{array}$ & $\begin{array}{c}\text { Betonarme } \\
\text { Radye }\end{array}$ & 2,5 & 300 & 8 & 50 & Betonarme & 8 & Betonarme \\
\hline Tekfen Tower (2003) & 120 & $34(7)$ & Ofis & $\begin{array}{c}\text { Çekirdek+Çevre } \\
\text { Kolon }\end{array}$ & $\begin{array}{l}\text { Betonarme } \\
\text { Radye }\end{array}$ & 2,9 & 400 & 7,5 & $40 / 60 / 75$ & Betonarme & 7,5 & Betonarme \\
\hline $\begin{array}{l}\text { Selenium Residence } \\
\text { (2004) }\end{array}$ & 120 & $30(5)$ & Konut & $\begin{array}{c}\text { Çekirdek+Çevre } \\
\text { Tüp }\end{array}$ & $\begin{array}{c}\text { Betonarme } \\
\text { Radye }\end{array}$ & 3 & 400 & 8 & 110 & Betonarme & 9 & Betonarme \\
\hline $\begin{array}{l}\text { Uphill Towers Kule } 1 \text { ve } \\
2(2008)\end{array}$ & 120 & $36(5)$ & Konut & $\begin{array}{l}\text { Çekirdek+Çevre } \\
\text { Kolon }\end{array}$ & $\begin{array}{l}\text { Betonarme } \\
\text { Radye }\end{array}$ & 2 & 300 & 7 & 32 & Betonarme & 7 & Betonarme \\
\hline $\begin{array}{l}\text { Kozyatağı iş Merkezi } \\
\text { (2003) }\end{array}$ & 119 & $30(5)$ & Ofis & $\begin{array}{c}\text { Çekirdek+Çevre } \\
\text { Kolon } \\
\end{array}$ & $\begin{array}{c}\text { Betonarme } \\
\text { Radye }\end{array}$ & 2,5 & 385 & 6,5 & 60 & Betonarme & 6,5 & Betonarme \\
\hline $\begin{array}{l}\text { Zorlu Plaza / Gelişim } \\
\text { Tower (2001) }\end{array}$ & 118 & $30(1)$ & $\begin{array}{c}\text { Ofis / } \\
\text { Üniversite } \\
\end{array}$ & $\begin{array}{c}\text { Çekirdek+Çevre } \\
\text { Tüp }\end{array}$ & $\begin{array}{l}\text { Betonarme } \\
\text { Kazık Temel }\end{array}$ & 40 & 370 & 8 & 60 & Betonarme & 5 & Betonarme \\
\hline Kanyon Kule (2006) & 118 & $30(8)$ & $\begin{array}{l}\text { AVM/Konut } \\
\text { /Ofis }\end{array}$ & $\begin{array}{c}\text { Çekirdek+Çevre } \\
\text { Kolon }\end{array}$ & $\begin{array}{c}\text { Betonarme } \\
\text { Radye }\end{array}$ & 2,5 & 400 & 8 & 75 & Betonarme & 8 & Betonarme \\
\hline Apa Giz Plaza (2008) & 112 & $32(7)$ & Ofis & $\begin{array}{c}\text { Çekirdek+Çevre } \\
\text { Kolon }\end{array}$ & $\begin{array}{l}\text { Betonarme } \\
\text { Radye }\end{array}$ & 2 & 340 & 9 & 50 & Betonarme & 9 & Betonarme \\
\hline Maslak Sheraton (1992) & 99 & $27(5)$ & Otel & $\begin{array}{c}\text { Çekirdek+Çevre } \\
\text { Kolon }\end{array}$ & $\begin{array}{c}\text { Betonarme } \\
\text { Radye }\end{array}$ & 3 & 360 & 9,6 & 50 & Betonarme & 9,6 & Betonarme \\
\hline İz Plaza Giz (2003) & 91 & $28(6)$ & Ofis & $\begin{array}{c}\text { Çekirdek+Çevre } \\
\text { Tüp }\end{array}$ & $\begin{array}{c}\text { Betonarme } \\
\text { Radye }\end{array}$ & 2 & 320 & 8,2 & 40 & Betonarme & 4,1 & Betonarme \\
\hline $\begin{array}{l}\text { Harmancı Giz Plaza } \\
(2001)\end{array}$ & 90 & $24(5)$ & Ofis & $\begin{array}{c}\text { Çekirdek+Çevre } \\
\text { Tüp } \\
\end{array}$ & $\begin{array}{c}\text { Betonarme } \\
\text { Radye }\end{array}$ & 2 & 320 & 8,2 & 40 & Betonarme & 4,1 & Betonarme \\
\hline Giz 2000 Plaza (1999) & 90 & $23(3)$ & Ofis & $\begin{array}{c}\text { Çekirdek+Çevre } \\
\text { Tüp } \\
\end{array}$ & $\begin{array}{c}\text { Betonarme } \\
\text { Radye }\end{array}$ & 2 & 320 & 8,2 & 40 & Betonarme & 3 & Betonarme \\
\hline Spring Giz Plaza (1994) & 90 & $27(3)$ & Ofis & $\begin{array}{c}\text { Çekirdek+Çevre } \\
\text { Tüp }\end{array}$ & $\begin{array}{c}\text { Betonarme } \\
\text { Radye }\end{array}$ & 2 & 320 & 7 & 40 & Betonarme & 3,5 & Betonarme \\
\hline
\end{tabular}

Belirlenen çok katlı yapılar, kirişli, kirişsiz, nervürlü, kaset, ön germeli ve ard germeli döşeme cinsleri bakımından incelenmiş, bu inceleme sonucunda $\% 52$ oranında kaset döşeme sisteminin, $\% 40$ oranında ise iki doğrultuda çalışan kirişli döşeme sisteminin, $\% 4$ oranında mantar döşeme sisteminin ve $\% 4$ oranında nervürlü döşeme sisteminin tercih edildiği Tablo 2'de görülebilmektedir. Söz konusu yapılarda $\% 52$ oranında tercih edilen kaset döşeme sistemlerinin $10 \mathrm{~cm}$ ile $40 \mathrm{~cm}$ arasında kalınlığa sahip olduğu, ortalamada ise, $21,23 \mathrm{~cm}$ olduğu görülmektedir. İki doğrultuda kirişli döş̧eme sistemlerinin $12 \mathrm{~cm}$ ile $20 \mathrm{~cm}$ arasında değişkenlik gösterdiği ve ortalamada ise $17,40 \mathrm{~cm}$ olduğu görülebilmektedir. 
European Journal of Science and Technology

Tablo 2. İstanbul'daki Çok Katlı Yapıların Döşeme Sistemlerinin Karşılaştırılması

\begin{tabular}{|c|c|c|c|c|c|c|c|c|c|}
\hline \multirow{3}{*}{ Yapı İsmi } & \multicolumn{9}{|c|}{ Betonarme Döşeme Cinsi } \\
\hline & \multicolumn{2}{|c|}{ Kirişşiz Döşeme } & \multirow{2}{*}{ Nervürlü Döşeme } & \multirow{2}{*}{ Kaset Döşeme } & \multicolumn{3}{|c|}{ Kiriş̧i Döşeme } & \multirow{2}{*}{ Ön Germeli } & \multirow{2}{*}{ Ard Germeli } \\
\hline & Plak & Mantar & & & Tek D. & iki D. & Izgara & & \\
\hline \multirow{2}{*}{ istanbul Sapphire } & \multirow{2}{*}{ - } & \multirow{2}{*}{ - } & \multirow{2}{*}{ - } & * & \multirow{2}{*}{ - } & \multirow{2}{*}{ - } & \multirow{2}{*}{ - } & \multirow{2}{*}{ - } & \multirow{2}{*}{ - } \\
\hline & & & & Kalınlık $40 \mathrm{~cm}$ & & & & & \\
\hline \multirow{2}{*}{ iş Bankası Kule 1} & - & - & - & $*$ & - & - & - & - & - \\
\hline & & & & Kalınlık $38 \mathrm{~cm}$ & & 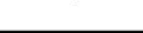 & & & - \\
\hline Sisliplaza & - & - & - & - & - & * & - & - & - \\
\hline (1) & & & & & 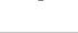 & Kalınlık $15 \mathrm{~cm}$ & & & \\
\hline Selenium Twins & - & - & - & $*$ & - & - & - & - & - \\
\hline Kule 1 ve 2 & - & - & - & Kalınlık $30 \mathrm{~cm}$ & $\cdot$ & $\cdot$ & $\cdot$ & - & - \\
\hline Koza Plaza Kule 1 ve & - & $*$ & - & - & - & - & - & - & - \\
\hline 2 & 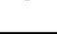 & Kalınlık $30 \mathrm{~cm}$ & 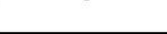 & 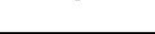 & 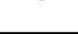 & - & & - & \\
\hline Metrocity R Blok & 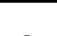 & 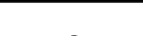 & 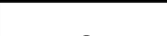 & 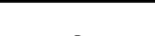 & 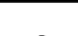 & * & 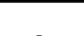 & 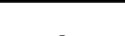 & 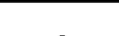 \\
\hline IVetrocty b Diok & & & - & - & & Kalınlık $15 \mathrm{~cm}$ & & & \\
\hline Sabancı Center Kule & - & 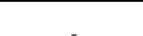 & - & - & - & $*$ & - & - & - \\
\hline 2 & 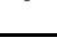 & 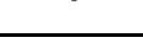 & 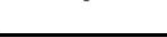 & 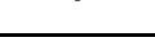 & 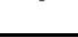 & Kalınlik $20 \mathrm{~cm}$ & 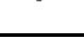 & - & 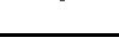 \\
\hline Garanti Bankası & - & . & - & - & - & $*$ & - & - & - \\
\hline Merkezi & - & $\cdot$ & - & - & - & Kalınlık $20 \mathrm{~cm}$ & $\cdot$ & $\cdot$ & - \\
\hline Beybi Giz Plaza & 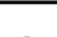 & 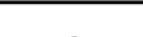 & - & * & 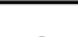 & 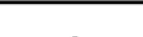 & & & \\
\hline Beybi Giz Plaza & 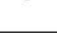 & - & - & Kalınlık $10 \mathrm{~cm}$ & $\cdot$ & - & - & - & - \\
\hline Süzer Plaza & . & - &. & $*$ & 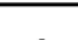 & - & - & - & ${ }^{2}$ \\
\hline | suzer praza & $\cdot$ & 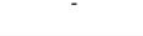 & - & Kalınlık $40 \mathrm{~cm}$ & - & - & - & - & - \\
\hline Elit Residence & - & - & - & $*$ & - & & - & - & - \\
\hline Elit Residence & - & - & - & Kalınlık $10 \mathrm{~cm}$ & - & - & - & - & $\cdot$ \\
\hline Astoria Kule 1 ve 2 & - & - & - & - & - & $*$ & - & - & - \\
\hline Astoria Kule 1 ve 2 & - & - & - & $\cdot$ & $\cdot$ & Kalınlık $18 \mathrm{~cm}$ & - & - & - \\
\hline Yapı Kredi Merkez & & & & & & $*$ & & & \\
\hline & & & & & & Kalınlık $20 \mathrm{~cm}$ & & & \\
\hline & 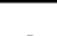 & 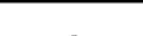 & 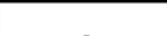 & 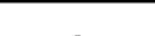 & 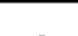 & $*$ & 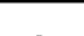 & 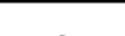 & 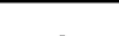 \\
\hline Tekfen Tower & - & - & - & $\cdot$ & $\cdot$ & Kalınlık $14 \mathrm{~cm}$ & $\cdot$ & $\cdot$ & - \\
\hline Selenium Residence & - & - & - & - & - & $*$ & - & - & - \\
\hline Selenium Kesidence & - & - & - & - & - & Kalınlık $20 \mathrm{~cm}$ & - & - & \\
\hline Uphill Towers Kule & - & - & - & * & - & - & - & - & - \\
\hline 1 ve 2 & - & - & - & Kalınlık $10 \mathrm{~cm}$ & - & - & - & - & - \\
\hline Kozyatağı Iş & - & - & - & - & - & * & - & - & - \\
\hline Merkezi & & - & - & - & - & Kalınlık $12 \mathrm{~cm}$ & - & - & 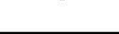 \\
\hline Zorlu Plaza / Gelişim & - & - & - & - & - & $*$ & - & - & - \\
\hline Tower & & - & - & & & Kalınlık $20 \mathrm{~cm}$ & - & - & \\
\hline Kanyon Kule & - & - & * & - & - & - & - & - & - \\
\hline & & & Kalınlık $12 \mathrm{~cm}$ & & & & & & \\
\hline Apa Giz Plaza & - & - & - & $*$ & - & - & - & - & - \\
\hline & & & & Kalınlık $40 \mathrm{~cm}$ & 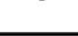 & ${ }^{*}$ & ${ }^{*}$ & 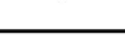 & 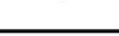 \\
\hline Maclak Shernton & 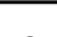 & 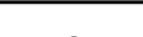 & 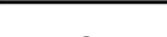 & $*$ & 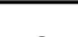 & 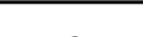 & 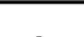 & 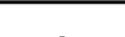 & 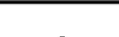 \\
\hline |Viastak Sneraton & 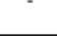 & - & - & Kalınlık $18 \mathrm{~cm}$ & $\cdot$ & - & - & - & 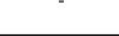 \\
\hline 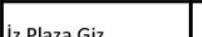 & - & 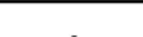 & 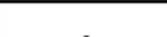 & $*$ & 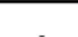 & - & 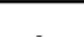 & 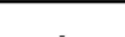 & 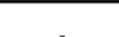 \\
\hline 12 Miazd or & 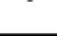 & - & $\cdot$ & Kalınlik $10 \mathrm{~cm}$ & $\cdot$ & $\cdot$ & $\cdot$ & 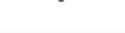 & 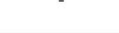 \\
\hline Harmanci Giz Plaza & - & - & - & $*$ & - & - & - & - & - \\
\hline Па & 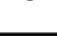 & $\cdot$ & $\cdot$ & Kalınlık $10 \mathrm{~cm}$ & $\cdot$ & $\cdot$ & $\cdot$ & 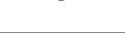 & ${ }^{*}$ \\
\hline Giz 2000 Plaza & . & - & - & $*$ & - & . & - & - & - \\
\hline Giz 2000 plaza & - & - & - & Kalınlık $10 \mathrm{~cm}$ & $\cdot$ & $\cdot$ & $\cdot$ & $\cdot$ & $\cdot$ \\
\hline Spring Giz Plaza & - & - & - & $*$ & - & - & - & - & - \\
\hline & & & 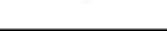 & Kalınlık $10 \mathrm{~cm}$ & 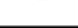 & & 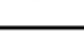 & 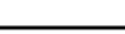 & \\
\hline
\end{tabular}

\section{Sonuç}

Teknolojinin gelişmesi ve şehirlerin her geçen zaman diliminde daha fazla kalabalıklaşması çok katlı binaların ortaya çıkmasında önemli olmuştur. Şehir merkezlerinde yaşanan nüfus artışları sonucu, yatayda yapılan konut yapıları yetersiz kalmış ve kullanıcıların ihtiyacına cevap verememiştir. Bu durum, çok katlı yapılara olan ihtiyacı ortaya çıkarmıştır. Çok katlı yapılar tasarlanırken en önemli etken taşıyıcı sistemdir. Çok katlı yapılar ile az katlı yapıları ayıran diğer bir önemli unsur da, taşıyıcı sistemleri tasarlanırken düşey yüklere ek olarak yatay yüklerin de hesaba katılması gerektiğidir. Bu gereklilikler, birçok taşıyıcı sistem çeşidinin ortaya çıkmasını sağlamıştır. 
Bu çalışmada, İstanbul'da yer alan ve 1992 - 2010 yılları arasındaki, 18 yıllık sürede tamamlanmış, yirmi beş adet çok katlı yapı incelenmiş, çeşitli kriterler üzerinden değerlendirilmiştir. İlgili yapıların yapı yüksekliğine bakıldığında, ortalama yükseklik olarak 131 metre düzeylerinde olduğu görülmüştür. Kat adetlerine bakıldığında, ortalamada 34,24 adet kat sayısına sahip oldukları ve bu kat adetlerinin ortalamada 5,48 adet düzeyinde bodrum kata sahip olduğu görülmüştür. Yapılarda, \%64 oranında ofis fonksiyonu tercih edilmiştir. Söz konusu yapıların tamamına yakınında çekirdek ve çerçeve tüp / kolon sistemin kullanıldığı görülürken, radye temel cinsinin \%96 oranında tercih edildiği ve ortalamada $240 \mathrm{~cm}$ temel kalınlığına sahip oldukları görülmüştür. Yapıların kat yüksekliklerinin ortalama $368 \mathrm{~cm}$ olduğu ve kiriş açıklıklarının ortalamada $790 \mathrm{~cm}$ düzeyinde, kiriş kalınlıklarının ise ortalamada $53,33 \mathrm{~cm}$ düzeyinde olduğu görülmüștür. İlgili yapıların ortalamada $710 \mathrm{~cm}$ kolon açıklıklığına sahip olduğu ve \%96'lık oranda betonarme radye temelin kullanıldığı görülebilmektedir. Yapıların döşeme sistemleri incelendiğinde ise \%52'lik bir kısmının kaset döşeme, \%40’lık bir kısmının ise iki doğrultuda çalışan kirişli döşeme sistemi ile inşa edildiği görülmüştür.

\section{Kaynakça}

Acar, E. (1999). Neolitik- Kalkolitik Çağ, Tunç Çağı Kentleri, ed. Y. Sey, Tarihten Günümüze Anadolu’ da Konut ve Yerleşme, Tarih vakfi Yayınları, İstanbul.

Akurgal, E. (2005). Anadolu Kültür Tarihi, TÜBİTAK Yayınları, Başak Matbaacılık, Ankara.

Alabçın, M. (1991). Türkiye'de 1985- 1990 Dönemi Yüksek Bina Projeleri, Yüksek Lisans Tezi, İ.T.Ü. Fen Bilimleri Enstitüsü, İstanbul.

Ali, M., Moon, K. S. (2007). Structural Developments in Tall Buildings: Current Trends and Future Prospects, Champaign, USA.

Anonim 1. (1997). Yenilikler, Hürriyet Gazetesi, 7 Aralık 1997.

Ardıç, H. (1993). Betonarme Yüksek Yapıların Taşıyıcı Sistemlerinin İncelenmesi ve Tüp Taşıyıcı Sistemli Yüksek Yapının Dinamik Hesab1, Yüksek Lisans Tezi, İstanbul Teknik Üniversitesi İnşaat Fakültesi, İstanbul.

Aslanoğlu, İ. N. (1980). 1923- 1938 Erken Cumhuriyet dönemi Mimarlığı, Ankara.

Aydınöz, A. A. (1995). Yüksek Yapılar ve İnsan, Mimarlık Dekorasyon, S: 31, S:64.

Aytıs, S. (1991). Yüksek Yapıların Gelişimine Toplu Bir Bakış, Yapı Dergisi, S:116, S:46.

Aytıs, S. (1991). Yüksek Yapılarda Yaşam, Yapı Dergisi, S:121, S:49.

Bayır, L. (1988). Türkiye' de Yüksek Yapıların Başlangıç ve Gelişmesi, Yüksek Lisans Tezi, İstanbul Teknik Üniversitesi İnşaat Fakültesi, İstanbul.

Bektaş, C. (1989). Yüksek Yapılar ve Mersin Gökdeleni, Yapı Dergisi, Say1 89, -Nisan 1989, S: 62.

Beyazoğlu, İ. T. (1997). Yüksek Yapılarda Tübüler Taşıyıcı Sistemler ve Uygulama Örnekleri, Yüksek Lisans Tezi, M.S.Ü. Fen Bilimleri Enstitüsü, İstanbul.

Büyüklü, K. (1998). Çok Katlı Yüksek Yapılarda Çekirdekli Sistemler ve Uygulama Örneklerinin İncelenmesi, Yüksek Lisans Tezi, Mimar Sinan Üniversitesi Mimarlık Bölümü, İstanbul.

Çelik, M. D. (2003). Yüksek Yapılarda Çelik Taşıyıcı Sistemler, Yüksek Lisans Tezi, İstanbul Teknik Üniversitesi Fen Bilimleri Enstitüsü, İstanbul.

Coşkun, A. Tanaçan, L. (1989). Yüksek Yapıların Tasarım Sorunları, Yüksek Yapılar I. Ulusal Sempozyumu, Bildiriler Kitabı, sf:287, İstanbul Teknik Üniversitesi.

Diez, E. (1995). Türk Sanatı 2, İstanbul.

Ersoy, D.O. (1993). Yüksek Binalarda Tasarım İlkeleri, Yüksek Lisans Tezi, Yıldız Teknik Üniversitesi Mimarlık Fakültesi, İstanbul.

Ersoy, U. Çıtıpıtıoğlu, E. (1976). Yüksek Yapıların Tasarım ve Yapımında İzlenecek Temel İlkeler, İ.T.Ü İnşaat Fakültesi Matbaası, İstanbul.

Göçer, O. (1969). Gökdelenler, Mimarlık Dergisi, S: 27.

Günel, M. H. Ilgın, H. E. (2010). Yüksek Binalar Taşıyıcı Sistem ve Aerodinamik Form, ODTÜ Mimarlık Fakültesi Basım İşliği, Ankara.

Işık, M. (2008). Çok Katlı Betonarme Yapılarda Taşıyıcı Sistem Etkisi, Yüksek Lisans Tezi, İstanbul Teknik Üniversitesi Fen Bilimleri Enstitüsü, İstanbul.

Kabarık, Y. (1991). İstanbul'da Yüksek Binalar ve Beşiktaş- Levent- Maslak Örneği, Yüksek Lisans Tezi, İstanbul Teknik Üniversitesi Mimarlık Fakültesi, İstanbul.

Karataş, H. (1979). Asma Sistemler, İTÜ Mimarlık Fakültesi, İstanbul.

Kejanlı, T. (2005). Anadolu' da İlk Yerleşmeler ve Kentleşme Eğilimleri, Doğu Anadolu Bölgesi Araştırmaları, Dicle Üniversitesi Mühendislik Mimarlık Fakültesi, Mimarlık Bölümü, Diyarbakır.

Kırkan, H. S. (2005). Çok katlı Yüksek Yapıların Tasarımına Etki Eden Faktörlerin İrdelenmesi, Yüksek lisans tezi. Dokuz Eylül Üniversitesi, İzmir.

Konyar, E. (2014). Mezopotamya Tarihi, İstanbul Üniversitesi Açık ve Uzaktan Eğitim Programı, İstanbul.

Mir, M. A. Kyoung S. M. (2011). Structural Developments in Tall Buildings: Current Trends and Future Prospects, Architectural Science Review,

Özgen, A. (1989). Çok Katlı Yüksek Yapıların Tarihsel Gelişimi ve Son Aşama: Tübüler Sistemler, Yapı Dergisi, S: 89, S: 47.

Özgen, A. (1989). Çok Katlı Yüksek Yapılarda Taşıyıcı Sistemler, Mimar Sinan Üniversitesi Mimarlık Bölümü, İstanbul.

Özgen, A. Sev, A. (2000). Çok Katlı Yüksek Yapılarda Taşıyıcı Sistemler, Birsen Yayınevi, İstanbul.

Özşen, G. Yamantürk E. Akdumanlar, E. (1989). Çok Katlı Çelik Yapıların Tasarım İlkeleri, Yapı Dergisi, S: 43.

Özşen, G. Yamantürk, E. (1991). Taşıyıcı Sistem Tasarımı, Birsen Yayınevi, İstanbul.

Piroğlu, F. (2001). Çok Katlı Çelik Yapılar, Yapısal Çelik Haftası Seminerleri, İTÜ Ayazağa Kampüsü, İnşaat Fakültesi, İstanbul.

Rafainer, F. (1968). Hochhaeuser", Bauverlag Gmbh, Berlin. 
Sağlam, M. R. (2016). Yüksek Yapılar İstanbul'dan Örnekler, Nobel Yayıncılık, Ankara.

Schueller, W. (1977). "High- Rise Building Structures", John Wiley \& Sons, New York, 1993- Çeviri: "Yüksek Yapı Taşıyıcı Sistemleri", E. Yamantürk-G. Özşen.

Şener, A. Z. (1995). Büro Binalarında Çekirdek Çözümü, Yüksek Lisans Tezi, Yıldız Teknik Üniversitesi Mimarlık Fakültesi, İstanbul.

Turani, A. (1979). Dünya Sanat Tarihi, Ankara.

Tümer, Ö. H. (2006). Dışa Kapalı Konut Yerleşmelerinin Bursa' da ki Örnekler Kapsamında Değerlendirilmesi, Yüksek Lisans Tezi, Uludağ Üniversitesi, Bursa.

Ünal, M. (1979). Türkiye'de Apartman Olgusunun Gelişimi, Çevre, 4, İstanbul.

Yılmaz, A. B. (1992). Yükseklik Tutkusu ve Gökdelenlerin Gelişimi, Dizayn Konstrüksiyon Dergisi, S: 79, S: 43.

Yeang, K. (2000). Service Cores, John Wiley \&Sons Inc., New York

Yünüak, M. (1996). Büro Plan Düzeni Tasarımı İçin Bilgisayar Destekli Bir Mimari Tasarım Modeli, Yüksek Lisans Tezi, İstanbul Teknik Üniversitesi $\quad$ Fen $\quad$ Bilimleri

URL-1: http://arfen.com.tr/ard-germe-nedir (Erişim Tarihi: 05.04.2018)

URL-2: https://www.designingbuildings.co.uk/wiki/Prestressed_concrete (Erişim Tarihi: 18.07.2018)

URL-3: https://people.utm.my/shamsulhadi/meeting-2-slides/shb-prestressed-concrete-space-007/ (Erişim Tarihi: 13.09.2018)

URL-4: http://sterlingpk.com/en/services-2/index.html (Erişim Tarihi: 07.01.2019)

URL-5: https://www.amsyscoinc.com/products-services/monostrand-post-tension/ (Erişim Tarihi: 13.02.2019)

URL-6: $\quad$ https://vasshaug.net/2013/02/27/post-tension-structures-in-revit/ 